Article

\title{
Hydrologic Responses to Climate Variability and Human Activities in Lake Ziway Basin, Ethiopia
}

\author{
Mulugeta Musie $^{1}\left(\mathbb{D}\right.$, Sumit Sen ${ }^{1, *(\mathbb{D})}$ and Indrajeet Chaubey ${ }^{2}$ \\ 1 Department of Hydrology, Indian Institute of Technology Roorkee, Roorkee, Uttarakhand 247667, India; \\ mulliemu@gmail.com \\ 2 College of Agriculture, Health and Natural Resources, University of Connecticut, 1376 Storrs Road, \\ Unit 4066, Storrs, CT 06269, USA; indrajeet.chaubey@uconn.edu \\ * Correspondence: ssenhfhy@iitr.ac.in
}

Received: 20 October 2019; Accepted: 2 January 2020; Published: 5 January 2020

\begin{abstract}
Hydrological impacts of human activities and climate variability on Ketar and Meki watersheds of Lake Ziway basin, Ethiopia were studied using the soil and water assessment tool. Three land-use change and two climate variability scenarios were considered to analyze the separate and combined impacts on annual water balance, monthly streamflow, and spatial distributions of evapotranspiration and water yield. The evaluation showed that changes in land use resulted in an increase in annual surface runoff and water yield for Ketar watershed and an increase in annual ET for Meki. Similarly, the climate variability resulted in a decrease in annual ET, surface runoff, and water yield for Ketar watershed and a decrease in ET for Meki. Overall, climate variability has greater impacts on the monthly streamflow compared to land-use change impacts. Similarly, greater sensitivity in hydrologic response was observed for Ketar watershed compared to Meki watershed.
\end{abstract}

Keywords: Central Rift Valley; Lake Ziway; SWAT model; land-use change; climate variability; Scenario analysis

\section{Introduction}

Climate variability and change in land use are among the most influential factors affecting the hydrologic responses of a watershed. Climate variability affects the temporal and spatial distribution of precipitation and temperature. As a result, the time to peak, peak discharge, and total streamflow can be affected [1-3]. Land-use change affects the hydrology of a watershed in terms of base flow, surface runoff, and sediment and nutrient yields. Similarly, frequency, depth, and duration of a flood can also be affected following the changes in the amount of interception, infiltration, and evapotranspiration from precipitation and temperature variability [4-7].

The hydrological systems of different basins, specifically closed lake basins, in Africa have been affected by multiple forces including climate variabilities in addition to factors like socio-economic activities, population growth, and national development policies, which resulted in an intensive land-use change [8,9]. Hydrological systems of lakes and reservoirs are good sentinels of human activities and natural impacts on water resources [10-12]. According to Coe and Foley [11], Lake Chad's water balance responds rapidly to the impacts of human intervention and climate variability due to its shallowness. Consequently, the lake area was reduced from $24,000 \mathrm{~km}^{2}$ in the 1950 s to $1700 \mathrm{~km}^{2}$ representing a net reduction of $90 \%$ in the lake area [13-15]. This reduction has enormously changed and affected the livelihoods and lives of many people and habitats living in the area [16].

Similarly, the water levels of lakes in Ethiopia have also shown changes following the impacts of human activities and climate variability. Three lakes found in the Ethiopian Rift Valley, i.e., Lake Beseka, Lake Awassa, and Lake Chamo, have shown an increase in volume while Lake Abiyata has 
shown a reduction. According to Ayenew [17], between 1976 and 1997, Lake Beseka's water level rose by $4 \mathrm{~m}$ with a corresponding increase in the area of the lake from $2.5 \mathrm{~km}^{2}$ in the $1950 \mathrm{~s}$ to $40 \mathrm{~km}^{2}$. The change in volume of the lake is due to an increase in groundwater recharge from the nearby irrigation fields and an increase in the regulated flow of Awash River following the construction of the upstream Koka dam $[17,18]$. Both Lake Awassa and Chamo have also shown an increase in volume since the 1980s. The fluctuating and increasing trends of Lake Awassa's water level were mainly related to the increase in precipitation, while some studies attributed the contributions of neo-tectonism and changes in land use $[19,20]$. According to Ayenew [17], the probable cause of an increase in the water level of Lake Chamo was related to the changes in land use in the Abaya lake basin.

Lake Alamaya is another lake in Ethiopia, which was adversely affected by human activities and climate variabilities. The lake was the major source of water for irrigation, fishery, and domestic uses. Following the excessive expansion of irrigation, uncontrolled water withdrawal, and an increasing rate of evapotranspiration [21], the volume of the lake has reduced drastically. According to Lemma [22], the maximum depth of the lake has reduced from about $8 \mathrm{~m}$ to $3 \mathrm{~m}$ and its surface area from $4.72 \mathrm{~km}^{2}$ to $2.12 \mathrm{~km}^{2}$ between the mid-1980s and 2000. In addition, the excessive erosion and deposition of sediment in Lake Alemaya due to changes in land use and uncontrolled deforestation in the watershed have also contributed to the reductions in lake storage capacity [23]. These and other human and natural induced factors have aggravated the reduction in volume and the danger of total disappearance of Lake Alemaya.

Perhaps the most serious lake water level change has been observed in Lake Abiyata of the central rift valley (CRV) basin in Ethiopia. The basin consists of chains of interconnected rivers, wetlands, and lakes, with a diverse ecosystem and topography. Lake Ziway, located upstream of lake Ariyata, is the largest freshwater lake in the basin and the only source of fish production in the area. The central rift valley basin is also known to be the habitat of about $50 \%$ of the country's bird species including those found only in Ethiopia and a variety of flora and fauna species [24,25]. The sources of inflow to Lake Abiyata are mainly from the discharges of Lake Ziway and the other upstream Lake Langano. Being a closed basin, a relatively small human intervention and climate variability can result in far-reaching consequences on the available water resource of the system $[8,17]$. Evaporation loss from the surface of the lakes, excessive pumping of water from the lakes, and withdrawal from the feeder rivers for irrigation, soda extraction, and domestic supply have resulted in a rapid decrease in volume of Lake Abiyata to about $50 \%$ of its original size since the 1970s. In addition, a considerable amount of increase in intensively cultivated areas and other land-use changes that affected the surface runoff of the system are also reported [26].

Studies conducted to evaluate the impacts of the natural factors and an increase in population and the related socio-economic developments on the water resources of the central rift valley basin recommended a detailed analysis $[8,24,26,27]$. A number of studies have been conducted to analyze the impacts of land use and climate changes on water resources in Ethiopia. However, none of them tried to understand the impacts simultaneously and to quantitatively assess the combined impact in terms of hydrologic responses. Evaluating the impacts of land-use changes and climate variability is important to discern the effects of each of these factors [28-36]. Both land use and climate change may have positive or negative impacts on various components of hydrologic cycles, primarily driven by the nature and magnitude of the change. For example, a shift from barren land to forested land may increase evapotranspiration and base flow. The same can be true for climate variability depending upon the shift in precipitation and temperature patterns. Discerning these impacts will enable watershed mangers to prepare effective strategies to improve water availability, water quality, and agricultural production. The main objectives of this study are, therefore, (i) to evaluate the trends of the changes in climate variability and land uses between 1984 and 2017 and (ii) to simulate the corresponding spatial and temporal hydrologic responses of the two main feeder river watersheds of Lake Ziway basin using the soil and water assessment tool (SWAT). To our best knowledge, the model has been used in many types of research to study the impacts of the changes in land use or climate variability 
on the hydrologic responses [27,37-43]; however, only a few studies have been done to evaluate the combined impacts of the two changes [44,45].

\section{Materials and Methods}

\subsection{Study Area}

Lake Ziway (Figure 1) is the only freshwater lake among the central rift valley basin natural lakes. It serves as the source of water supply for the Ziway town and the surroundings. In addition, a higher amount of water is also being pumped from the lake to irrigate small and large-scale private-owned and state-owned farms. Lake Ziway is located about $165 \mathrm{~km}$ south of the capital Addis Ababa at an elevation of $1638 \mathrm{~m}$ above sea level. It is a shallow lake with an average depth of $4 \mathrm{~m}$ and covering an area of about $435 \mathrm{~km}^{2}$. The two main feeder rivers Meki and Ketar drain into the lake from the eastern and western highlands, respectively. The overflow from Lake Ziway flows downstream into the terminal Lake Abiyata.

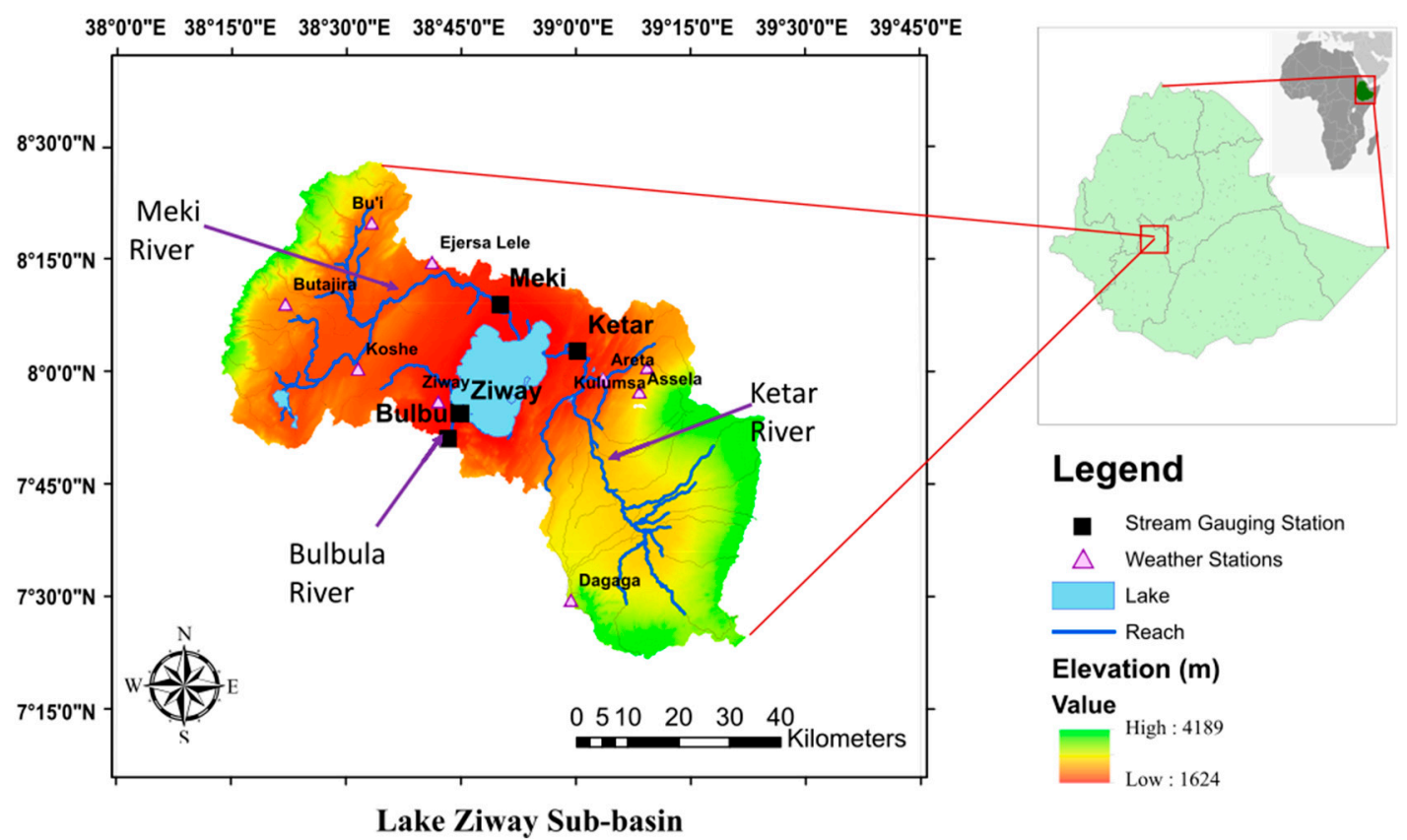

Figure 1. Location map of the study area showing the twelve river basins of Ethiopia, Lake Ziway basin, stream gauging, and meteorological stations, the two main feeder rivers, Ketar and Meki, and Lake Ziway.

The total area of Lake Ziway basin including the lake is about $7311 \mathrm{~km}^{2}$ and it is located between $7^{\circ} 22^{\prime} 12^{\prime \prime} \mathrm{N}$ to $8^{\circ} 28^{\prime} 12^{\prime \prime} \mathrm{N}$ latitude and $38^{\circ} 12^{\prime} 36^{\prime \prime} \mathrm{E}$ to $39^{\circ} 24^{\prime} 36^{\prime \prime}$ E longitude (Figure 1) [46]. The temporal and spatial variability of the climate in Lake Ziway basin is high. The average mean annual temperature of the area varies from $21^{\circ} \mathrm{C}$ in the lowland parts of the rift floor around the lake to $16^{\circ} \mathrm{C}$ in the western and eastern highland parts of the basin [26]. The mean annual precipitation varies from $1200 \mathrm{~mm} / \mathrm{year}$ in regions with a higher altitude to $700 \mathrm{~mm} /$ year around the rift floor with a mean annual precipitation of about $900 \mathrm{~mm} /$ year over the entire basin. Percentages of precipitation falling during the main rain season (June to September), small rain season (March and May), and dry season (December to February) are $59 \%, 28 \%$, and $13 \%$ of the total precipitation, respectively [47]. In the years 1994 and 1995, the actual evapotranspiration of the basin was recorded and ranged from $900 \mathrm{~mm} /$ year in the eastern and western highlands to $650 \mathrm{~mm} / \mathrm{year}$ in the central part of the rift floor [48]. The amount of water being lost from the Lake Ziway surface through evaporation was estimated to be about $1800 \mathrm{~mm} /$ year [49]. 


\subsection{Data Collection and Analysis}

\subsubsection{Land Use/Land Cover (LULC) Change Analysis}

Hydrologic impact assessment of land-use change on water resources can be done by using either a static or dynamic approach. In a static approach, the model run output of the initial land-use is compared with the model run output of the final land-use. While the model run with dynamic land-use is compared with the model run with the initial land-use in the dynamic approach. The dynamic approach is particularly important in areas where there are dynamic land-use changes following urbanization and the rapid development of socio-economy [50]. However, due to the unavailability of recurrent land-use data, especially in developing countries such as Ethiopia, and the limited capabilities of models to handle dynamic land-use changes for the evaluation period, the dynamic approach was rarely used. Following the availability of frequent satellite imagery, land-use change models and the improvements in the model capabilities, including SWAT model, dynamic land-use setups are the current state-of-the-art in impact assessment studies than static land-use [28,51,52]. However, most of the land-use changes including agricultural land expansions have already occurred in the study area during the periods preceding hydrologic assessment done in this study (before the 1960s) and therefore the temporal development is not the main focus of this study. Therefore, the static land-use setup is used in this study.

Satellite information from remote sensing was used to study the changes in land use/land cover (LULC) on Lake Ziway basin during the last three decades. Landsat Multispectral Scanner for the year 1984, Landsat Thematic Mapper for the year 2000, and Enhanced Landsat Thematic Mapper Plus for the year 2017 were downloaded from the US Geological Survey website using earth explorer (http://earthexplorer.usgs.gov) to detect the changes in LULC and classify the land uses of the basin. Satellite imagery maps of December months with the lowest cloud cover and moisture content were selected to get a representative reflectance signature. Ground truth points and Google Earth images were used to associate and verify the spectral classes of each LULC maps to analyze the changes. Maximum likelihood algorithm of ERDAS Imagine 2016 software was used to classify the satellite images and identify the classes based on the LULC maps of the basin used in previous studies [8,27].

Accuracy assessment was done using a reference data sample of 282, 296, and 319 points for the 1984, 2000, and 2017 images, respectively, to validate the information derived. A confusion matrix based on the reference points was used to derive Kappa coefficients and overall accuracies. Assessment of the classification accuracy was done using the error matrix by cross-tabulating the reference class versus the mapped classes [53]. Classification areas were calculated to identify the changes in the percentage of each land-use class.

\subsubsection{Climate Variability and Trend Analysis}

The test for the detection of the significant long-term monotonic trends of the monthly and annual precipitation and mean temperature were analyzed using a non-parametric statistical test, i.e., Mann-Kendall and the Sen's slope estimator. The Mann-Kendall test statistic [54-56] is given as follows:

$$
Z=\left\{\begin{array}{cc}
\frac{S-1}{\sqrt{\operatorname{Var}(S)}} & \text { if } S>0 \\
0 & \text { if } S=0 \\
\frac{S+1}{\sqrt{\operatorname{Var}(S)}} & \text { if } S<0
\end{array}\right.
$$

in which

$$
S=\sum_{i=1}^{n-1} \sum_{j=i+1}^{n} \operatorname{sgn}\left(x_{j}-x_{i}\right)
$$


where

$$
\begin{gathered}
\operatorname{sgn}\left(x_{j}-x_{i}\right)=\left\{\begin{array}{l}
+1, \text { if } x_{j}-x_{i}>0 \\
0, \text { if } x_{j}-x_{i}=0 \\
-1, \text { if } x_{j}-x_{i}>0
\end{array}\right. \\
\operatorname{Var}(S)=\frac{n(n-1)(2 n+5)-\sum_{i=1}^{m} t_{i}\left(t_{i}-1\right)\left(2 t_{i}+5\right)}{18}
\end{gathered}
$$

where $S$ is a Mann-Kendall statistic and $V$ is variance.

Sen's slope [57] is another useful non-parametric index used to estimate the slope of the monotonic trend in the sample of $\mathrm{N}$ pairs of data:

$$
Q_{i}=\frac{x_{j}-x_{k}}{j-k} \text { for } i=1, \ldots, N
$$

where $x_{j}$ and $x_{k}$ are the data values at times $j$ and $k(j>k)$, respectively.

\subsubsection{Hydrologic and Watershed Data Assimilation}

A $30 \mathrm{~m}$ resolution digital elevation model data of the National Aeronautics and Space Administration Shuttle Radar Topographic Mission was downloaded from the US Geological Survey website (http://earthexplorer.usgs.gov). The Harmonized World Soil Database of the Food and Agriculture Organization digital soil map from http://www.fao.org/data/en/ was used to extract the soil properties. Landsat images downloaded from the United States Geological Survey were used to interpret the temporal and spatial variations of the land use patterns. River discharge data of Meki and Ketar rivers used for calibration and validation of the SWAT model were obtained from the Ethiopian Ministry of Water Resources, Hydrology Department. Observed maximum and minimum temperature and precipitation data used for driving the hydrologic model were provided by the Ethiopian National Meteorological Agency. Other daily meteorological data for the period from 1979 to 2013 were downloaded from Global Weather Data for SWAT.

\subsection{Hydrologic Modeling}

\subsubsection{SWAT Model Setup}

An ArcGIS interface Arc SWAT 2012 model developed by the United States Department of Agriculture-Agricultural Research Service was used for hydrologic modeling. SWAT is a physically based, spatially distributed, and continuous watershed or river-basin-scale hydrologic model [58]. In fact, the model is developed with the capability to study small-scale to large and complex watersheds with varying land use, soil, and slope classes. The SWAT can evaluate the long-term impacts of different land management and climate variability/change on biomass production, water quantity, water quality, and sediment yield with the capability to study large-scale and complex watersheds for longer periods [59]. In such a model, a watershed is partitioned into a number of sub-watersheds, which are further sub-partitioned into the hydrologic response unit (HRUs). The water balance equation is used in the SWAT model to simulate the hydrologic cycle and predict the hydrology in each HRU. The model also provides users with different options to choose for the simulation of the hydrologic process. Penman-Monteith, Hargreaves, or Priestley-Taylor equation for potential evapotranspiration and Green-Ampt or curve number method for infiltration simulation can be chosen [5]. The detailed description of the hydrological equations used and different model components can be obtained in the SWAT documentation [59]. Because of the availability of discharge data, Scenario 0 (S0) was built for both watersheds during the period from 1980 to 1993 using the land use map of 1984. The model was run at a monthly time scale providing two years of warming up period. 


\subsubsection{SWAT Calibration and Validation}

An auto-calibration and uncertainty analysis tool, SWAT Calibration and Uncertainty Program (SWAT-CUP), was used to calibrate the model and to identify the parameters that are more sensitive [60]. Among the available analysis techniques built-in SWAT-CUP, the parallel Sequential Uncertainty Fitting Version 2 was used for this study. Discharge data collected from the Ethiopian Ministry of Water Resources were used for the calibration and validation of the SWAT model in both watersheds. The datasets from 1980 to 1993 were selected based on the availability of continuous monthly discharge data. The calibration and validation periods for the Meki and Ketar watersheds were divided based on continuous data availability, and two months of missing data were omitted during the calibration of Ketar watershed. Accordingly, the datasets from 1982 to 1986 and from 1987 to 1991 were used for model calibration and validation, respectively, of Meki watershed (2224 $\mathrm{km}^{2}$ area). Similarly, datasets from 1985 to 1989 for model calibration and from 1991 to 1993 for validation were used for Ketar watershed (3283 $\mathrm{km}^{2}$ area). Nash-Sutcliffe efficiency (NSE), percent bias (PBIAS), the ratio of mean square error to the standard deviation of the measured data (RSR), and $t$-test were used to assess and compare the hydrologic model performance with the observed discharge data. Equations (5)-(7) were used to determine the statistical objective functions.

$$
\begin{aligned}
\text { NSE } & =1-\frac{\sum_{i=1}^{n}\left(O_{i}-S_{i}\right)^{2}}{\sum\left(O_{i}-\bar{O}\right)^{2}} \\
\text { PBIAS } & =\frac{\sum_{i=1}^{n}\left(O_{i}-S_{i}\right) \times 100}{\sum_{i=1}^{n}\left(O_{i}\right)} \\
\text { RSR } & =\frac{\sqrt{\sum_{i=1}^{n}\left(O_{i}-S_{i}\right)^{2}}}{\sqrt{\sum_{i=1}^{n}\left(O_{i}-\bar{O}\right)^{2}}}
\end{aligned}
$$

where $O_{i}$ is the observed discharge, $S_{i}$ is the simulated discharge, $\bar{O}$ is the average measured discharge, $\bar{S}$ is the average simulated discharge, and $n$ is the number of observations.

\subsection{Scenario Analysis}

Although the utilization of water from Lake Ziway and its two main feeder rivers for irrigation was started in the 1970s, a major increase in irrigation area was observed after 2002 [26]. In order to evaluate the impact of changes in land use and climate variability on the water balance of the system, the calibrated SWAT model was simulated using the "one factor at a time" approach. The period from 1980 to 1993 was taken as the "baseline period" when the human activity was relatively less and the period from 2000 to 2013 was taken as the "human-impacted period" because of the rapid increase in irrigation and intensive cultivation. The land use map of 1984 was used to represent the baseline period when the human impact was not higher and the remaining two land use maps, 2000 and 2017, were used to represent the human-impacted periods. The SWAT model calibrated using the meteorological data of the baseline period and land use map of 1984 was represented as Scenario 0 (S0). The calibrated model was used to simulate the hydrologic responses using the remaining two human-impacted period land use maps (2000 and 2017) in combination with the pre and post impacted period climate data. Based on these combinations, the following three scenarios were developed to quantify the impacts of changes in land use and climate variability using the SWAT model output.

Scenario 1 (S1): 1980-1993 climate data and 2000 land use.

Scenario 2 (S2): 1980-1993 climate data and 2017 land use.

Scenario 3 (S3): 2000-2013 climate data and 2017 land use. 


\section{Results}

\subsection{LULC Change Analysis}

\subsubsection{LULC Classification Accuracy Assessment}

The maximum likelihood classification was used for the LULC classification of the satellite images. The seven broad LULC classifications of the basin include; agroforestry, woodland, waterbody, wetlands, cultivation, settlement, and afro-alpine (Table 1 and Figure 2). The LULC types confusion matrixes using ground validation points and google earth images show that the overall accuracy of the analysis of the LULC changes was above $80.5 \%$ and the overall kappa statistics were greater than 0.71 (Tables 2 and 3). The overall kappa statistics values reveal that the accuracy of the LULC classification is considerably good [61]. The producers' accuracy ranged from $60 \%$ for woodlands to $96 \%$ for waterbody and user's accuracy ranged from $72 \%$ for woodlands to $94 \%$ for wetlands.

Table 1. Description of the land use/land cover (LULC) classes [8] with the corresponding soil and water assessment tool (SWAT) codes and curve number (CN2) values for the Lake Ziway basin.

\begin{tabular}{|c|c|c|c|c|}
\hline $\begin{array}{c}\text { LULC } \\
\text { Classes }\end{array}$ & Description & $\begin{array}{l}\text { SWAT } \\
\text { Code }\end{array}$ & SWAT Description & $\begin{array}{c}\text { Curve } \\
\text { Number }\end{array}$ \\
\hline Agroforestry & Cultivated lands with spots of woods in between & AGRC & Agricultural land-Close grown & 81 \\
\hline Woodlands & Degraded Acacia land with cultivation/grazing & FRST & Forest-mixed & 73 \\
\hline Waterbody & Lakes and ponds & WATR & Water & 98 \\
\hline Wetland & Wetlands around water bodies & WETF & Wetlands-forested & 77 \\
\hline Cultivation & Intensively cultivated lands & AGRL & Agricultural land-Generic & 83 \\
\hline Settlement & Small towns and built-up areas & URML & Urban Medium Density & 82 \\
\hline Afro-alpine & Afro-alpine bushland, shrubs, and grasses & RNGB & Range-Shrubland & 74 \\
\hline
\end{tabular}

Table 2. Overall Kappa statistics and over accuracy of 1984, 2000, and 2017 LULC maps.

\begin{tabular}{cccc}
\hline Category & $\mathbf{1 9 8 4}$ & $\mathbf{2 0 0 0}$ & $\mathbf{2 0 1 7}$ \\
\hline Overall Kappa statistics & 0.71 & 0.72 & 0.75 \\
Overall Accuracy (\%) & $80.5 \%$ & $81.4 \%$ & $84 \%$ \\
\hline
\end{tabular}

\subsubsection{LULC Changes}

Like most parts of the Ethiopian Central Rift Valley basin, because of the denser agrarian population in the area, Lake Ziway basin LULC is dominated by agricultural lands (Figure 2). The sum of cultivation and agroforestry classes cover more than $70 \%$ of the total area of the basin while the wetland and settlement total area is less than $2.5 \%$ of the total area (Table 4 ). Following an increase in population, settlement and cultivation classes showed consistent increasing trends from $0.2 \%$ to $1.1 \%$ and $37.0 \%$ to $44.9 \%$, respectively, while the afro-alpine class showed a decreasing trend from $12.8 \%$ to 7.2\% between 1984 and 2017 (Table 4 and Figure 3).

However, the changes in agroforestry and woodlands classes were inconsistent. Agroforestry areal percentage increased from $36.2 \%$ in 1984 to $37.8 \%$ in 2000 and decreased from $37.8 \%$ to $36.1 \%$ between 2000 and 2017; whereas the woodland areal percentage decreased from $6.8 \%$ to 3.3\% between 1984 and 2000 and increased to $3.6 \%$ in 2017. The change in areas of water bodies and wetlands were almost negligible. The increasing trends of cultivation land class correlated with the decreasing trends of the afro-alpine class showing that part of the afro-alpine land was converted to cultivation. 


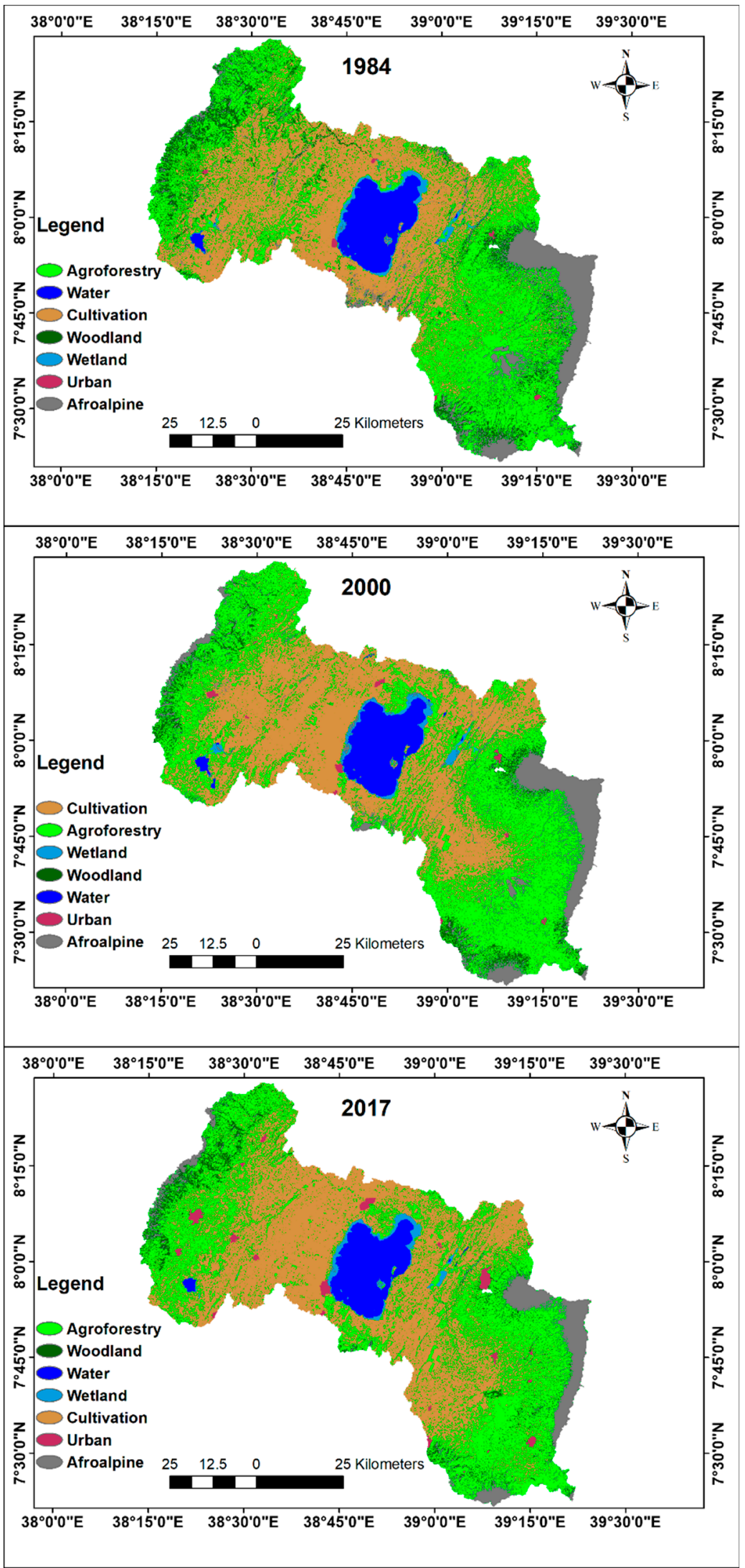

Figure 2. LULC classification maps of Lake Ziway basin for the years 1984, 2000, and 2017. 
Also, the change in the agroforestry land-use class correlated with the change in woodlands, i.e., when the areal percentage of agroforestry increased, the percentage of woodlands decreased and vice versa. Between 1984 and 2017, cultivation land class showed the highest change $(+7.9 \%)$, followed by afro-alpine $(-5.6 \%)$ and woodland $(-3.1 \%)$ classes.

Table 3. Error matrix (confusion matrix) for the 2017 classification LULC map accuracy assessment.

\begin{tabular}{|c|c|c|c|c|c|c|c|c|c|}
\hline \multirow{2}{*}{ Classified Data } & \multicolumn{8}{|c|}{ Reference Data } & \multirow{2}{*}{$\begin{array}{l}\text { Users } \\
\text { Accuracy }\end{array}$} \\
\hline & Agroforestry & Woodland & Waterbody & Wetland & Cultivation & Settlement & Afro-alpine & Row Total & \\
\hline Agroforestry & 84 & 2 & 0 & 0 & 9 & 0 & 1 & 96 & $88 \%$ \\
\hline Woodland & 1 & 19 & 0 & 0 & 0 & 0 & 1 & 21 & $90 \%$ \\
\hline Wetland & 1 & 1 & 1 & 12 & 0 & 0 & 0 & 15 & $80 \%$ \\
\hline Cultivation & 14 & 0 & 0 & 0 & 96 & 7 & 0 & 117 & $82 \%$ \\
\hline Settlement & 0 & 0 & 0 & 0 & 3 & 12 & 0 & 15 & $80 \%$ \\
\hline Producers Accuracy & $80 \%$ & $76 \%$ & $96 \%$ & $86 \%$ & $89 \%$ & $63 \%$ & $91 \%$ & & \\
\hline
\end{tabular}

Table 4. The areal statistical distribution of the LULC classes of 1984, 2000, and 2017 maps.

\begin{tabular}{|c|c|c|c|c|c|c|}
\hline \multirow{2}{*}{ Classes } & \multicolumn{2}{|l|}{1984} & \multicolumn{2}{|l|}{2000} & \multicolumn{2}{|l|}{2017} \\
\hline & Area $\left(\mathrm{km}^{2}\right)$ & Area (\%) & Area $\left(\mathrm{km}^{2}\right)$ & Area (\%) & Area $\left(\mathrm{km}^{2}\right)$ & Area (\%) \\
\hline Agroforestry & 2647.6 & 36.2 & 2768.9 & 37.8 & 2644.0 & 36.1 \\
\hline Water body & 430.0 & 5.9 & 434.7 & 5.9 & 427.1 & 5.8 \\
\hline Cultivation & 2709.3 & 37.0 & 2938.7 & 40.2 & 3285.5 & 44.9 \\
\hline Woodland & 494.7 & 6.8 & 240.1 & 3.3 & 265.3 & 3.6 \\
\hline Wetland & 84.6 & 1.2 & 83.5 & 1.1 & 85.6 & 1.2 \\
\hline Settlement & 13.9 & 0.2 & 26.0 & 0.4 & 81.9 & 1.1 \\
\hline Afro-alpine & 937.4 & 12.8 & 825.6 & 11.3 & 528.1 & 7.2 \\
\hline Total & 7317.5 & 100 & 7317.5 & 100 & 7317.5 & 100 \\
\hline
\end{tabular}

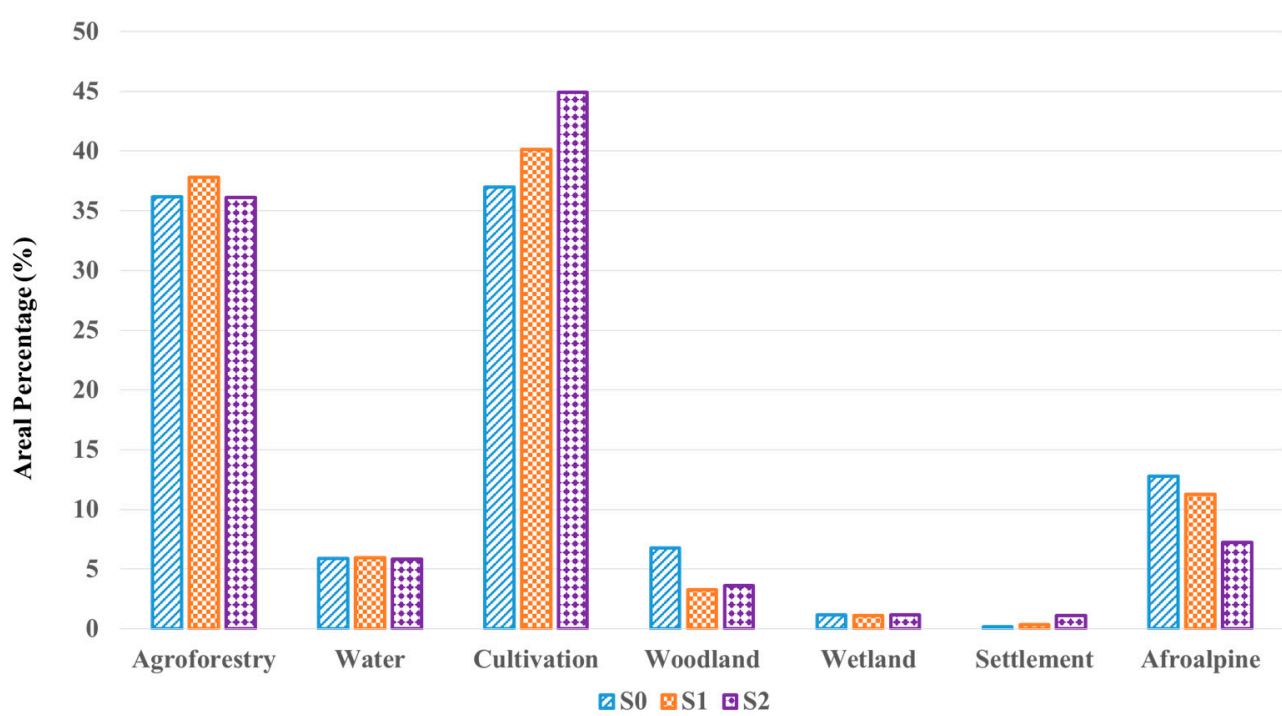

Figure 3. Land use classifications areal percentages of Lake Ziway basin under different scenarios.

\subsection{Climate Variability Analysis}

Global climate change and regional climate variability have a significant impact on the regional hydrological cycle, water resources availability, and natural ecosystem of an area [62]. In arid and semi-arid regions like Lake Ziway basin, the hydrologic response of a watershed is very sensitive to climate variability, specifically to changes in precipitation and temperature. Annual water balance analysis usually indicates that average annual precipitation is directly correlated with average annual 
surface runoff [63]. On the other hand, an increase in average annual temperature corresponds to a decrease in average annual surface runoff.

The monotonic trends of annual mean temperature and precipitations of the stations were different except the Ziway station $(P<0.05)$, where both the variables tended to increase (Tables A1 and A2 of the Appendix A). Although the trends of annual precipitation of seven stations out of the nine tended to increase from 1980 to 2013, the trend was significant only for two stations. Furthermore, the areal coverage of Bui station is relatively less and the Ejersa Lele station is located near the outlet of Meki Watershed.

The mean annual temperature showed a decreasing trend for three stations out of the five and were significant only at Ziway station. Detailed analysis of the changes in the trends are shown for the monthly data. Both increasing and decreasing trends were observed on the monthly precipitation and significant increases for the June and July were observed only for two stations. Similarly, a significant increase in mean monthly temperature was observed for 10 months at Ziway station.

The trend analysis results indicate that the climate was getting warmer in the rift floor and cooler in the highland areas. The monthly precipitations also showed both increasing and decreasing trends during the rainy season. Considerable influences on the hydrologic processes can be expected given such a variability in the climate data. An increase in precipitation during the rainy season is expected to increase the amount of discharge, while an increase in temperature generally results in an increase in the amount of evapotranspiration, and hence, a decrease in the amount of surface and subsurface discharges.

Therefore, to cover the relationships between the climate variability and the hydrologic responses, in this study, scenarios S2 and S3 were developed using the same land use map but different period's climate data.

Figures 4 and 5 also show the variability in average annual monthly precipitation and temperature for Meki and Ketar watersheds, respectively. Comparing the two figures and the two different scenarios, it can be observed that the temperature variability is higher for Meki watershed than Ketar. Also, the average monthly annual temperature of Meki watershed increased during the small rain season (March to May) and the main rainy season (June to August) and decreased during the remaining dry season.

However, the average monthly annual temperature of Ketar watershed decreased during the rainy season from May to September and increased during the dry season. The average annual monthly precipitation of both watersheds also showed changes that can affect the hydrologic response, especially during the main rainy season. However, the monthly average differences were more in Ketar watershed than Meki, unlike the changes in average monthly temperature. As shown in the results, temperature variability was more dominant in Meki watershed while precipitation variability was more in Ketar. The same difference was also reflected in the dry season climate of the two watersheds.

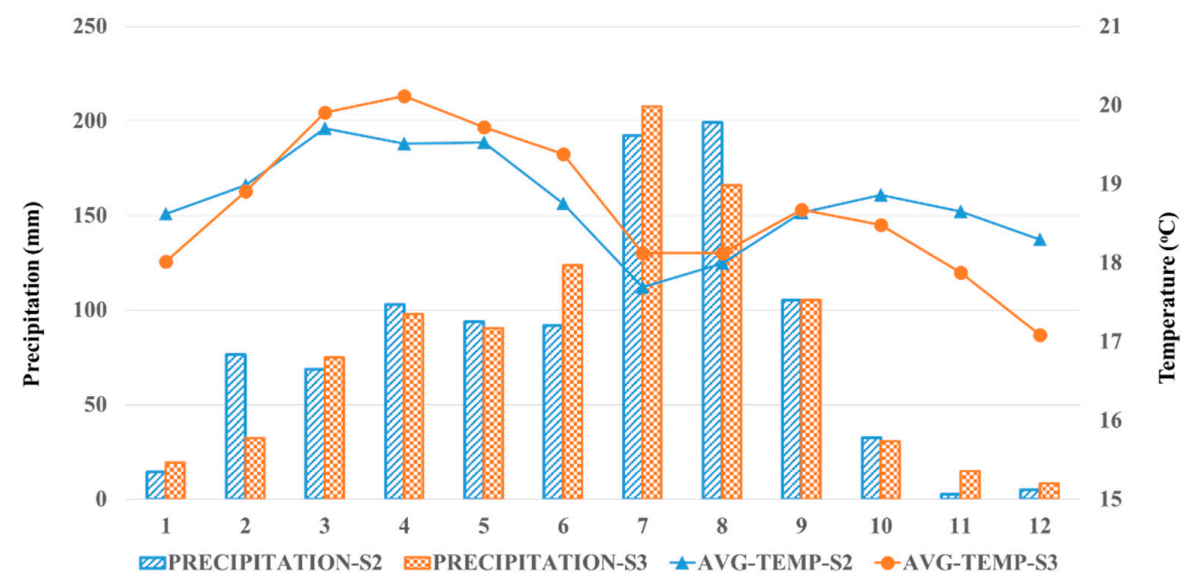

Figure 4. Changes in annual average precipitation and temperature in Meki watershed under scenarios S2 and S3. 


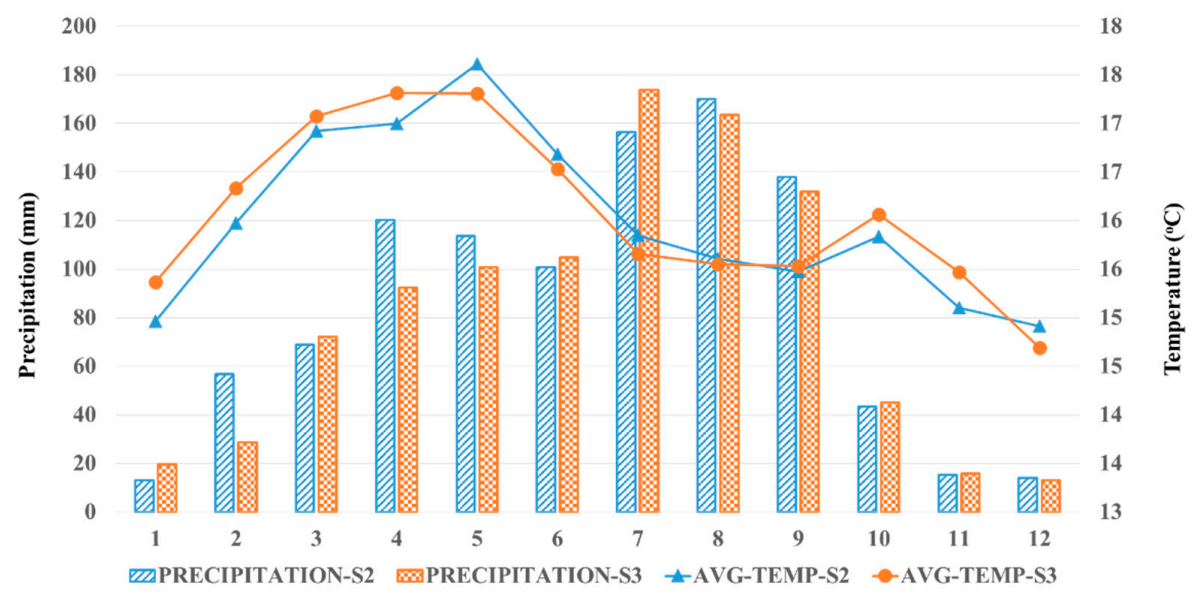

Figure 5. Changes in annual average precipitation and temperature in Ketar watershed under scenarios S2 and S3.

\subsection{Calibration and Validation of the SWAT Model}

The SWAT model was calibrated and validated using discharge data from Meki and Ketar gauging station of Lake Ziway basin based on the recommendation of [6] to calibrate the hydrologic model spatially for better analysis of the changes in land-use. The model simulated the observed discharge with good NSE (0.75), PBIAS (7.6), and RSR (0.50) values for the calibration period and NSE (0.70), PBIAS (0.08), and RSR (0.55) values for the validation period (Figure 6). The model simulated the observed discharge of Ketar watershed with very good NSE (0.83), PBIAS (7.1), and RSR (0.41) values for the calibration period and NSE (0.75), PBIAS (-5.02), and RSR (0.50) values for the validation period, showing that the model can be used for further monthly streamflow simulation (Figure 7). The $t$-test shown in Table 5 also reveals that the mean values of the observed and simulated discharges were not significantly different at a $95 \%$ level of confidence.

Sensitivity analyses of the 25 parameters used for calibration of the model were done using SWAT-CUP and the global sensitivity analysis result showed that CN2, HRU_SLP, ESCO, RCHRG_DP, ALPHA_BNK, SOL_AWC, EPCO, REVAPMN, and BIOMIX (Table 6) were found to be more sensitive. The calibrated models for both watersheds were run using the baseline period (1980-1993) meteorological data and the outputs were referred to as scenario 0 (S0) and the models were used with the land use maps and climate data of the remaining scenarios (S1, S2, and S3) to get the corresponding outputs.

Table 5. Goodness-of-fit statistics for the observed and simulated monthly streamflow for Ketar and Meki watersheds.

\begin{tabular}{|c|c|c|c|c|c|c|c|c|}
\hline \multirow{3}{*}{ Statistical Parameters } & \multicolumn{8}{|c|}{ Streamflow $\left(\mathrm{m}^{3} / \mathrm{s}\right)$} \\
\hline & \multicolumn{2}{|c|}{ Calibration Period } & \multicolumn{2}{|c|}{ Validation Period } & \multicolumn{2}{|c|}{ Calibration Period } & \multicolumn{2}{|c|}{ Validation Period } \\
\hline & Observed & Simulated & Observed & Simulated & Observed & Simulated & Observed & Simulated \\
\hline Mean & 10.76 & 10.00 & 11.72 & 12.31 & 6.44 & 5.94 & 7.22 & 7.22 \\
\hline Standard deviation & 13.31 & 11.71 & 14.94 & 13.46 & 7.90 & 7.06 & 8.11 & 7.32 \\
\hline t-stat & \multicolumn{3}{|c|}{1.07} & -0.76 & & 0.99 & \multicolumn{2}{|r|}{0.01} \\
\hline t-Critical two-tail & \multicolumn{2}{|r|}{2.00} & & 1.99 & \multicolumn{2}{|r|}{2.00} & \multicolumn{2}{|r|}{1.98} \\
\hline NSE & \multicolumn{2}{|r|}{0.83} & \multicolumn{2}{|r|}{0.75} & \multicolumn{2}{|r|}{0.75} & \multicolumn{2}{|r|}{0.70} \\
\hline PBIAS & \multicolumn{2}{|r|}{7.10} & \multicolumn{2}{|r|}{-5.02} & \multicolumn{2}{|r|}{7.60} & \multicolumn{2}{|r|}{0.08} \\
\hline RSR & \multicolumn{2}{|r|}{0.41} & \multicolumn{2}{|r|}{0.50} & \multicolumn{2}{|r|}{0.50} & \multicolumn{2}{|r|}{0.55} \\
\hline
\end{tabular}


Table 6. List of most sensitive parameters for Ketar watershed in descending order obtained by global sensitivity analysis.

\begin{tabular}{|c|c|c|c|c|c|}
\hline Rank & Name & Description & Initial Range & Fitted Range & Fitted Value \\
\hline 1 & r_CN2 & $\begin{array}{l}\text { Soil conservation service run-off curve } \\
\text { number for moisture condition II }\end{array}$ & {$[-0.25,0.25]$} & {$[-0.04,0.15]$} & $+0.014 \%$ \\
\hline 2 & v_HRU_SLP & Average slope steepness & {$[0,0.6]$} & {$[0.01,0.4]$} & 0.139 \\
\hline 3 & $\mathrm{v}_{-} \mathrm{ESCO}^{-}$ & Soil evaporation compensation factor & {$[0,1]$} & {$[0.24,0.91]$} & 0.277 \\
\hline 4 & $\mathrm{v}_{-}$RCHRG_DP & Deep aquifer percolation fraction & {$[0,1]$} & {$[0.06,0.40]$} & 0.101 \\
\hline 5 & v_ALPHA_BNK & Base flow alpha factor for bank storage & {$[0,1]$} & {$[0.23,0.64]$} & 0.603 \\
\hline 6 & r_SOL_AWC & Available water capacity of the soil layer & {$[-0.25,0.25]$} & {$[-0.22,0.09]$} & $-0.166 \%$ \\
\hline 7 & $\mathrm{v}_{-} \mathrm{EPCO}$ & Plant evaporation compensation factor & {$[0,1]$} & {$[0.41,0.89]$} & 0.596 \\
\hline 8 & $\mathrm{v}_{-}$REVAPMN & $\begin{array}{l}\text { Threshold depth of water in the shallow } \\
\text { aquifer for revap to occur }\end{array}$ & {$[0,500]$} & $\begin{array}{l}{[203.32} \\
498.36]\end{array}$ & 400.702 \\
\hline 9 & $\mathrm{v}_{-}$BIOMIX & Biological mixing efficiency & {$[0,1]$} & {$[0.10,0.57]$} & 0.306 \\
\hline
\end{tabular}

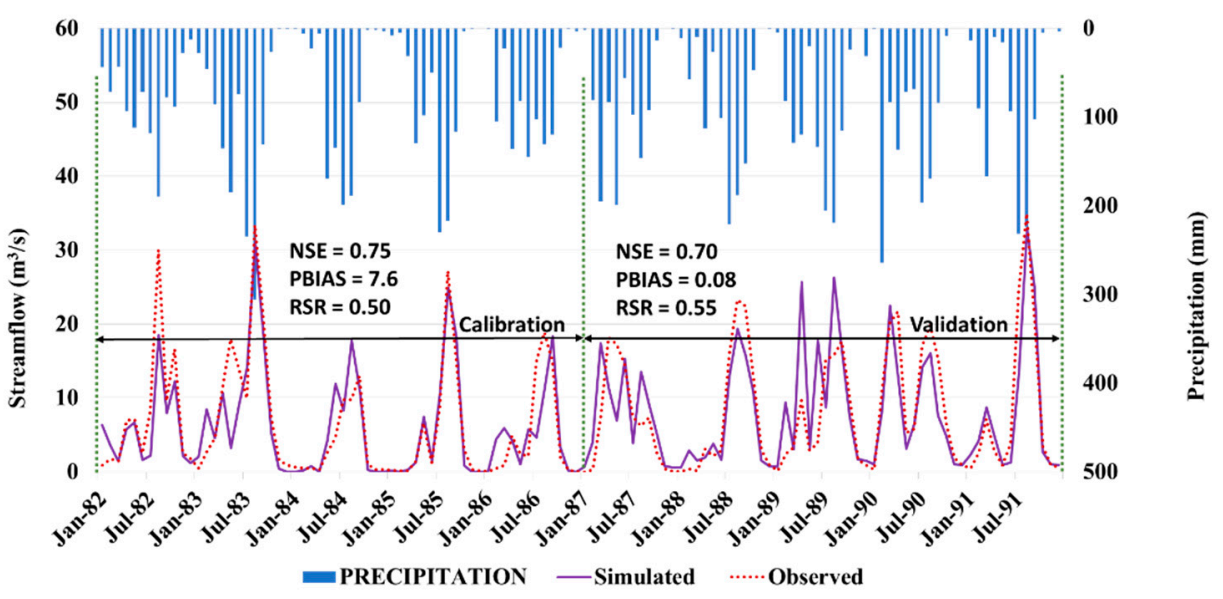

Figure 6. Simulated versus observed streamflow of Meki River under base period scenario (S0) for the calibration and validation periods.

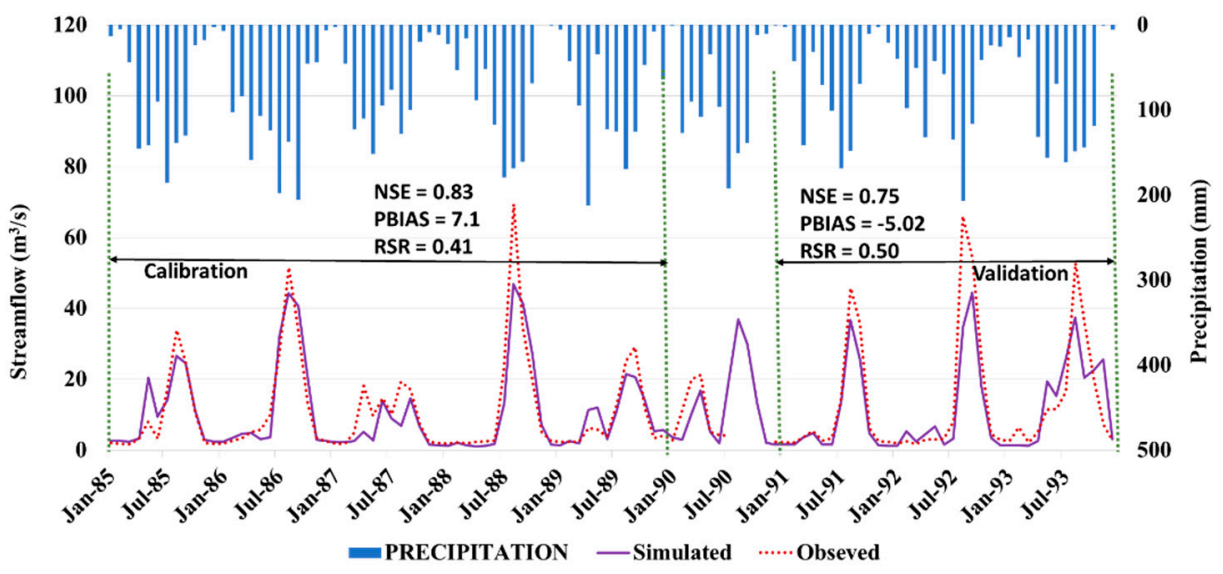

Figure 7. Simulated versus observed streamflow of Ketar River under base period scenario (S0) for the calibration and validation periods.

\subsection{Hydrologic Responses to Different Simulation Scenarios}

\subsubsection{Annual Water Balance in Different Land-Use Scenarios}

The impact of land-use changes on the annual water balance of Meki and Ketar watersheds under the three land-use scenarios (S0, S1, and S2) are shown in Tables 7 and 8, respectively. For Ketar watershed, the average annual surface runoff (SURQ) and Water yield (WYLD) showed a consistent increase and the average annual percolation (PERC) showed a consistent decrease for the land-use changes from S0 to S1 and S1 to S2. The changes in surface runoff, water yield, and percolation were 
higher for the land-use change between $S 0$ and $S 1,+11.0 \mathrm{~mm},+9.8 \mathrm{~mm}$, and $-12.9 \mathrm{~mm}$, respectively, than the values between S1 and S2, $+3.3 \mathrm{~mm},+2.1 \mathrm{~mm}$, and $-1.4 \mathrm{~mm}$, respectively. Compared to the change in values of the other components of the average annual water balance, the value of the change in evapotranspiration $(\mathrm{ET} ;+1.9 \mathrm{~mm}$ ) was less between the two land-use change periods.

Table 7. Annual water balance of Meki watershed due to climate variability and land-use changes.

\begin{tabular}{|c|c|c|c|c|c|c|c|c|}
\hline Scenarios & $\begin{array}{c}\text { Rainfall } \\
(\mathrm{mm})\end{array}$ & ET (mm) & $\begin{array}{l}\text { PET } \\
(\mathrm{mm})\end{array}$ & $\begin{array}{l}\text { PERC } \\
(\mathrm{mm})\end{array}$ & $\begin{array}{c}\text { SURQ } \\
(\mathrm{mm})\end{array}$ & $\begin{array}{l}\text { GWQ } \\
(\mathrm{mm})\end{array}$ & $\begin{array}{l}\text { WYLD } \\
\text { (mm) }\end{array}$ & $\begin{array}{l}\text { LATQ } \\
(\mathrm{mm})\end{array}$ \\
\hline S0 & 983.9 & 703.4 & 1973.9 & 186.3 & 96.3 & 10.5 & 110.9 & 4.2 \\
\hline S1 & 983.9 & 711.3 & 1974.8 & 175.4 & 97.4 & 10.1 & 111.1 & 3.7 \\
\hline S2 & 983.9 & 708.0 & 1973.0 & 180.8 & 96.0 & 10.2 & 110.3 & 4.1 \\
\hline S3 & 975.6 & 687.4 & 1988.7 & 194.5 & 95.5 & 10.4 & 110.2 & 4.3 \\
\hline
\end{tabular}

S0: 1980-1993 climate data and 1984 land use map, S1: 1980-1993 climate data and 2000 land use map, S2: 1980-1993 climate data and 2017 land use map, and S3: 2000-2013 climate data and 2017 land use map. GWQ: groundwater contribution to stream. LATQ: lateral flow contribution to stream.

In the case of Meki watershed, the annual average surface runoff and water yield showed an increase by $+1.1 \mathrm{~mm}$ and $+0.2 \mathrm{~mm}$, ET increased by $+7.9 \mathrm{~mm}$, and the annual average percolation decreased by $-10.9 \mathrm{~mm}$ during the first period of the land-use change (scenarios S0 and S1). In contrast, during the second period (scenarios S1 and S2) of the land-use change, the average annual surface runoff, water yield, and ET decreased by $-1.4 \mathrm{~mm},-0.9 \mathrm{~mm}$, and $-3.3 \mathrm{~mm}$, respectively, and average annual percolation increased by $+5.4 \mathrm{~mm}$.

Table 8. Annual water balance of Ketar watershed due to climate variability and land use changes.

\begin{tabular}{ccccccccc}
\hline Scenarios & $\begin{array}{c}\text { Rainfall } \\
(\mathbf{m m})\end{array}$ & ET $(\mathbf{m m})$ & $\begin{array}{c}\text { PET } \\
(\mathbf{m m})\end{array}$ & $\begin{array}{c}\text { PERC } \\
(\mathbf{m m})\end{array}$ & $\begin{array}{c}\text { SURQ } \\
(\mathbf{m m})\end{array}$ & $\begin{array}{c}\text { GWQ } \\
(\mathbf{m m})\end{array}$ & $\begin{array}{c}\text { WYLD } \\
(\mathbf{m m})\end{array}$ & $\begin{array}{c}\text { LATQ } \\
(\mathbf{m m})\end{array}$ \\
\hline S0 & 1032.6 & 738.0 & 1534.3 & 169.1 & 125.2 & 17.3 & 143.0 & 0.5 \\
S1 & 1032.6 & 739.9 & 1533.7 & 156.3 & 136.2 & 16.1 & 152.8 & 0.5 \\
S2 & 1032.6 & 738.0 & 1533.7 & 154.9 & 139.6 & 16.0 & 154.9 & 0.5 \\
S3 & 983.0 & 718.7 & 1645.9 & 131.6 & 132.5 & 13.0 & 145.9 & 0.4 \\
\hline
\end{tabular}

S0: 1980-1993 climate data and 1984 land use map, S1: 1980-1993 climate data and 2000 land use map, S2: 1980-1993 climate data and 2017 land use map, and S3: 2000-2013 climate data and 2017 land use map.

\subsubsection{Annual Water Balance in Different Climate Variability Scenarios}

Scenarios S2 and S3 were developed to study the impacts of climate variability on the hydrologic response of the basin. In both scenarios, the same land use (2017) but two different period climate data were used to evaluate how climate variability affects the water balance and streamflow of the system. For Meki watershed, annual average monthly precipitation and temperature changed between $-44.2 \mathrm{~mm}$ to $31.9 \mathrm{~mm}$ and $-1.2^{\circ} \mathrm{C}$ to $+0.6^{\circ} \mathrm{C}$, respectively, for different months. Similarly, for Ketar watershed, the changes varied from $-28.0 \mathrm{~mm}$ to $+6.7 \mathrm{~mm}$ for precipitation and from $-0.3^{\circ} \mathrm{C}$ to $+0.4^{\circ} \mathrm{C}$ for temperature, showing that the monthly climate variability for Meki watershed was higher both in precipitation and temperature than Ketar.

The impact of climate variability on the annual water balance of Meki and Ketar watersheds under the two climate scenarios (S2 and S3) was also analyzed as shown in Tables 7 and 8. For Meki watershed, the average annual precipitation and ET decreased by $8.3 \mathrm{~mm}$ and $20.6 \mathrm{~mm}$, respectively, resulting in a decrease in average annual surface runoff and water yield by less than $1 \mathrm{~mm}$ and an increase in average annual percolation by $13.7 \mathrm{~mm}$. On the other hand, for Ketar watershed, the decrease in average annual precipitation and ET by $49.6 \mathrm{~mm}$ and $19.3 \mathrm{~mm}$, respectively, resulted in a decrease in average annual surface runoff, water yield, and percolation by $7.1 \mathrm{~mm}, 9.0 \mathrm{~mm}$, and $23.3 \mathrm{~mm}$, respectively. This indicates that although the monthly temperature variability for Ketar watershed was less than that of Meki, the change in average annual water balance components of the 
watershed between the two scenarios was higher than the change for Meki watershed because of the higher decrease in average annual precipitation.

\subsection{Spatial Patterns of Hydrologic Responses in Different Scenarios}

The spatial distributions of average annual ET and changing rates in ET based on 19 sub-basins of Meki watershed and 25 sub-basins of Ketar watershed for the four scenarios S0, S1, S2, and S3 are shown in Figures 8 and 9, respectively. The spatial distributions of average annual water yield and changing rates in water yield for the developed scenarios are also shown in Figures 10 and 11.

\subsubsection{Spatial Patterns of ET and Its Changing Rate}

The top panels of Figure 8a-d illustrate the spatial distributions of the annual average ET in the 19 sub-basins of Meki watershed for different land use and climate scenarios (S0, S1, S2, and S3). From the result, it is observed that for scenario S0, the minimum, average, and maximum annual ET were $550 \mathrm{~mm}, 703.4 \mathrm{~mm}$, and $807.3 \mathrm{~mm}$, respectively. The minimum annual ET decreased to $549 \mathrm{~mm}$ and $547 \mathrm{~mm}$, the average annual ET increased to $711.3 \mathrm{~mm}$ and $708 \mathrm{~mm}$, and the maximum annual ET increased to $816.8 \mathrm{~mm}$ and $812.7 \mathrm{~mm}$ for the land-use scenarios S1 and S2, respectively. However, the minimum annual ET increased to $597 \mathrm{~mm}$, the average annual ET decreased to $687.4 \mathrm{~mm}$, and the maximum annual ET decreased to $754.2 \mathrm{~mm}$ for the climate variability scenario S3. In all three land-use scenarios, less than $600 \mathrm{~mm}$ of average annual ET was observed on the downstream sub-basins 7, 10, and 11 (Figure $8 \mathrm{a}-\mathrm{c}$ ) since the sub-basins are the intensively cultivated sub-basins with almost no woodlands. In addition, the average annual ET of greater than $800 \mathrm{~mm}$ was observed on the left side sub-basins covered by a considerable amount of woodlands and agroforestry. In the case of scenario S3, the average annual ET has changed in almost all sub-basins except sub-basins 4, 5, and 6 (Figure 8d) in response to the change in precipitation and temperature.

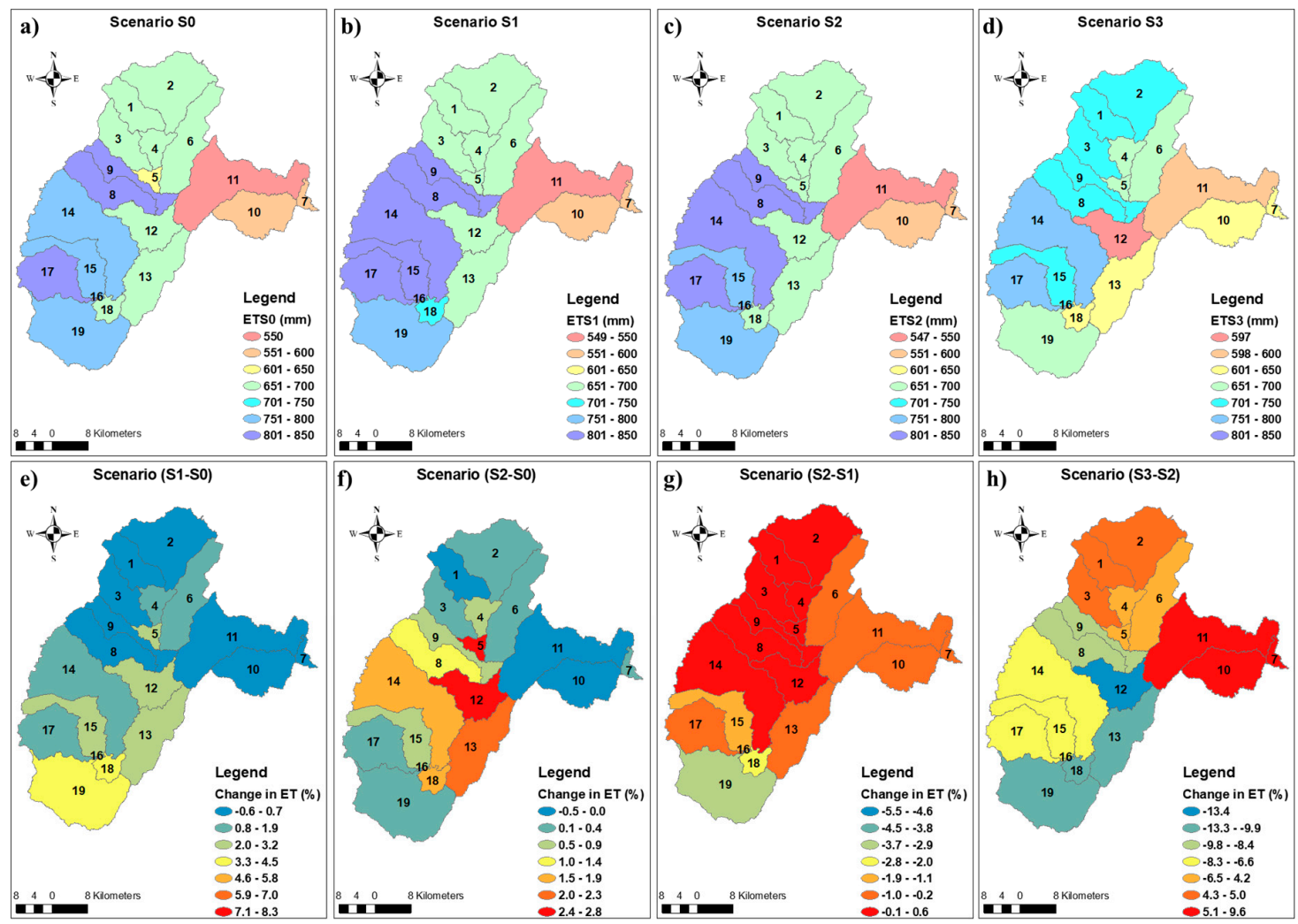

Figure 8. Spatial distribution of annual average and changing rates of evapotranspiration (ET) for different land-use scenarios $(\mathbf{a}-\mathbf{c}, \mathbf{e}-\mathbf{g})$ and climate variability scenario $(\mathbf{d}, \mathbf{h})$ in Meki watershed. 
The lower panels of Figure $8 \mathrm{e}-\mathrm{h}$ illustrates the spatial distributions of changing rates in average annual ET between the scenarios for Meki watershed sub-basins. Compared to scenario S0, the maximum decreasing rates of average annual ETs were $-0.6 \%$ and $-0.5 \%$ and the maximum increasing rates were $+4.5 \%$ and $+2.8 \%$ for scenarios S1 and S2, respectively. Compared to scenario S1, the maximum decreasing rate of average annual ET of S2 was $-3.7 \%$ and the maximum increase rate was $+0.6 \%$. Similarly, compared to scenario $\mathrm{S} 2$, the maximum decreasing rate of average annual ET of S3 was $-13.4 \%$ and the maximum increase rate was $+9.6 \%$, showing that the change rate was high for climate variability. Generally, the average annual ET and the changing rates between scenarios S0 and $\mathrm{S} 1$ and scenarios S0 and S2 presented increasing trends, while the trend between S1 and S2 showed decreasing; whereas the changing rate in ET resulted in both decreasing and increasing trends between S2 and S3.

Figure $9 a-d$ illustrates the spatial distributions of the annual average ET in the 25 sub-basins of Ketar watershed for different scenarios (S0, S1, S2, and S3). The minimum, average, and maximum annual ET for scenario S0 were $673 \mathrm{~mm}, 738 \mathrm{~mm}$, and $827 \mathrm{~mm}$, respectively. The minimum annual ET decreased to $669.6 \mathrm{~mm}, 670 \mathrm{~mm}$, and $660 \mathrm{~mm}$, the average annual ET became $739 \mathrm{~mm}, 738 \mathrm{~mm}$, and $718 \mathrm{~mm}$, and the maximum annual ET decreased to $810.2 \mathrm{~mm}, 793.5 \mathrm{~mm}$, and $789.8 \mathrm{~mm}$ for scenarios S1, S2, and S3, respectively. The average annual ET of about $76 \%$ of the total watershed for all the land-use scenarios was concentrated in the range of $700-800 \mathrm{~mm}$, while for the remaining $24 \%$ of the area, the ranges were between $670 \mathrm{~mm}$ and $700 \mathrm{~mm}$. However, the areal percentages of ET values in the range of 700-800 $\mathrm{mm}$ were lesser and the values with ET below $700 \mathrm{~mm}$ were higher in the case of scenario S3.

From Figure $9 \mathrm{e}-\mathrm{h}$, it can be observed that compared to S0, the maximum decreasing rates of average annual ET were $-2.3 \%$ and $-4.0 \%$ and the maximum increasing rates were $+6.1 \%$ and $+6.2 \%$ for scenarios S1 and S2, respectively. Compared to scenario S1, the maximum decreasing rate of S2 was $-2.1 \%$ and the maximum increase rate was $+2.7 \%$. Similarly, compared to $\mathrm{S} 2$, the maximum decreasing rate of $\mathrm{S} 3$ was $-5.0 \%$ and the maximum increase rate was $+1.0 \%$.

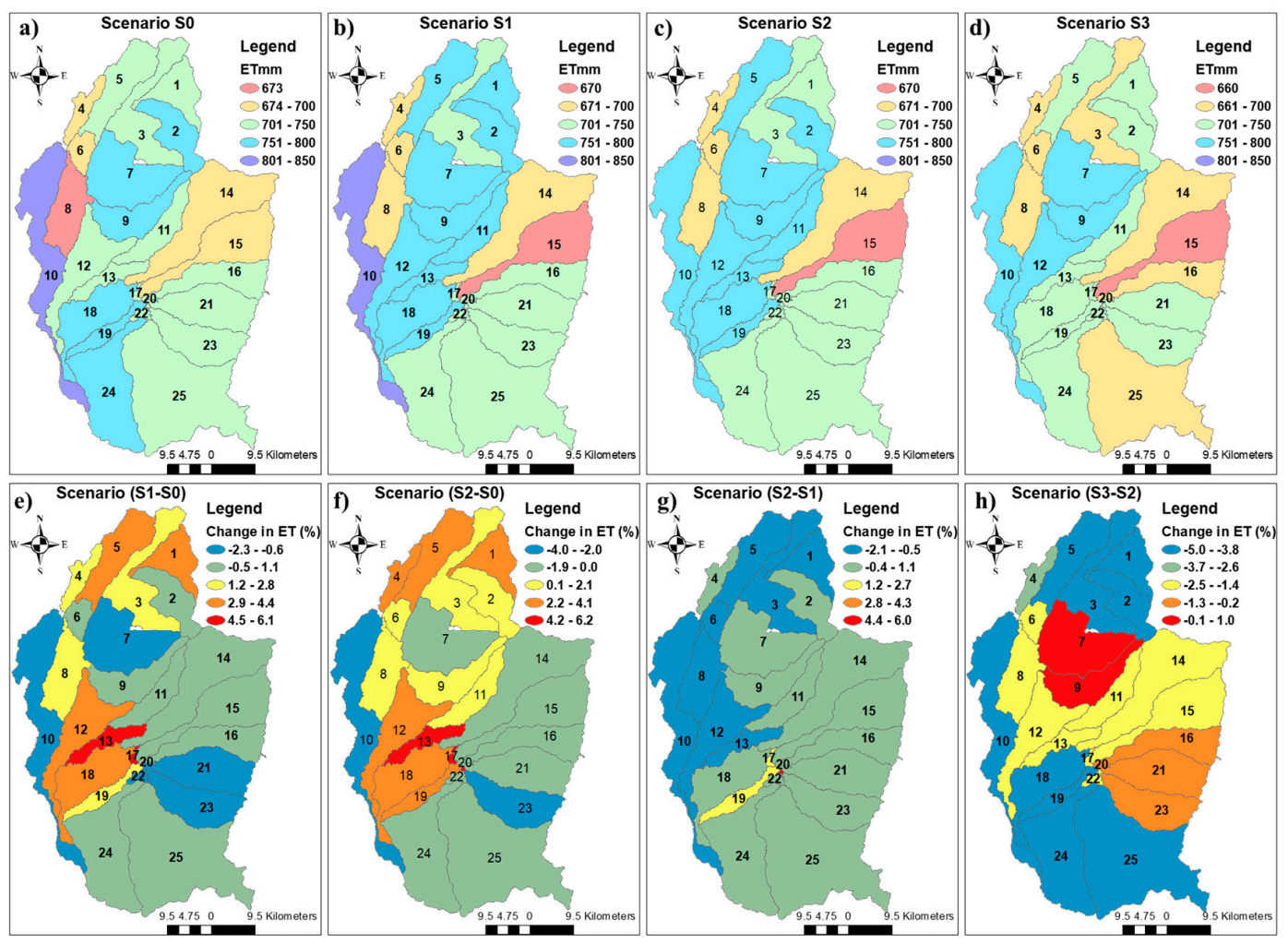

Figure 9. Spatial distribution of annual average and changing rates of ET for different land-use scenarios $(\mathbf{a}-\mathbf{c}, \mathbf{e}-\mathbf{g})$ and climate variability scenario $(\mathbf{d}, \mathbf{h})$ in Ketar watershed. 


\subsubsection{Spatial Patterns of Water Yield and Its Changing Rate}

The spatial distributions of the annual average water yield in the sub-basins of Meki watershed for all the scenarios (S0, S1, S2, and S3) are shown in the top panels of Figure 10a-d. The results show that the minimum and maximum water yields were $67.2 \mathrm{~mm}, 69.3 \mathrm{~mm}, 69.9 \mathrm{~mm}$, and $90.8 \mathrm{~mm}$ and $308.3 \mathrm{~mm}, 233.1 \mathrm{~mm}, 290.4 \mathrm{~mm}$, and $180.5 \mathrm{~mm}$, respectively. Similar to ET, less than $90 \mathrm{~mm}$ of average annual water yield was observed on the downstream sub-basins 7, 10, and 11 for all the land-use scenarios. Most of the sub-basins responded differently for S3 as compared to scenario S2. Comparing scenarios S1 and S0, two sub-basins, 1 and 3, showed a decrease while 13 and 18 showed an increase in water yield. Also, the water yields of sub-basin numbers 12, 13, 14, and 18 decreased when scenario S2 is compared with $\mathrm{S} 0$ and $\mathrm{S} 1$.

Figure 10e-h shows the spatial pattern of changes in the average annual water yield. The maximum decreases in water yield were $-10.9 \%$ and $-7 \%$ and the maximum increases were $6.8 \%$ and $8.5 \%$ between scenarios S1 and S2 and scenario S0, respectively. Whereas, between scenarios S1 and S2 and scenarios S2 and S3, the maximum reductions were $-5.6 \%$ and $-37.9 \%$ and increases were $11.6 \%$ and $55.5 \%$. Generally, water yield showed an increasing trend in most parts of the sub-basins between scenarios S1 and S0. However, it showed both increasing and decreasing trends between S2 and S0 and scenario S3 and S2 and a decreasing trend between S2 and S1.

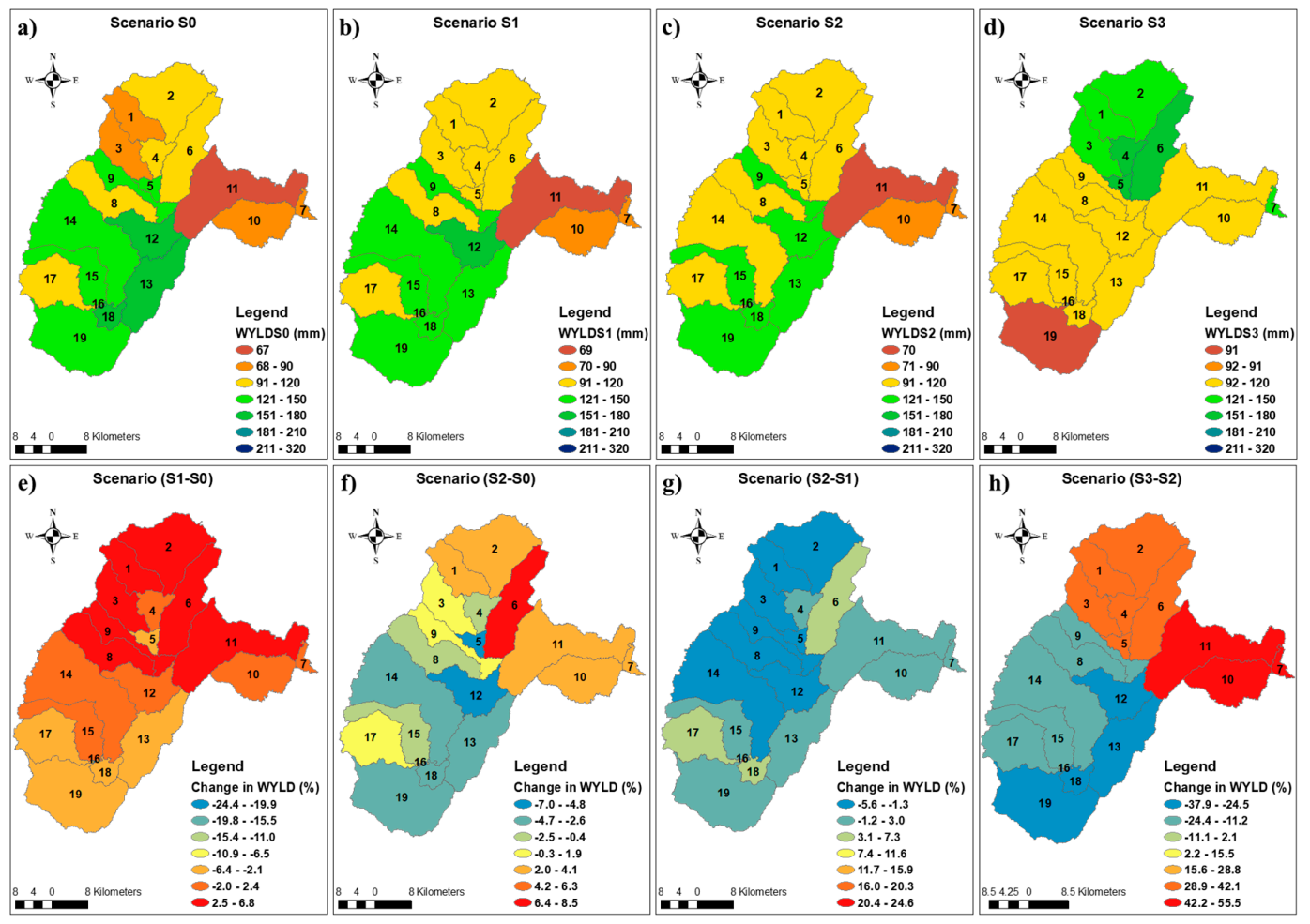

Figure 10. Spatial distribution of annual average and changing rates of WYLD for different land-use scenarios $(\mathbf{a}-\mathbf{c}, \mathbf{e}-\mathbf{g})$ and climate variability scenario $(\mathbf{d}, \mathbf{h})$ in Meki watershed.

Figure 11a-d showed that the minimum and maximum water yields were $50.5 \mathrm{~mm}, 61.5 \mathrm{~mm}$, $55.1 \mathrm{~mm}$, and $52.7 \mathrm{~mm}$ and $199.7 \mathrm{~mm}, 222 \mathrm{~mm}, 210.6 \mathrm{~mm}$, and $239.6 \mathrm{~mm}$ for scenarios S0, S1, S2, and S3, respectively, for Ketar watershed. For all the scenarios, water yield less than $90 \mathrm{~mm}$ was observed in the northern intensively cultivated sub-basins and water yield greater than $120 \mathrm{~mm}$ was observed in eastern highland and southern sub-basins. Generally, an increase in water yield was shown in most sub-basins and the higher increases were observed in the central and eastern sub-basins for all the land-use scenarios. Sub-basins with less water yield resulted in the same values for all the scenarios 
while an increase and a decrease in water yield among sub-basins were also observed in the case of scenario S3.

The lower panels of Figure 11e-h also showed that the maximum decreases in changing rate of water yield were $-16.5 \%$ and $-22.7 \%$ and the maximum increases were $24.7 \%$ and $31.3 \%$ between scenarios S1 and S2 and scenario S0, respectively. Also, between scenarios S1 and S2, the maximum decrease was $-27.8 \%$ and that of the increase was $32.8 \%$. Similarly, the rates were $-26.7 \%$ and $19.5 \%$, respectively, between scenarios S2 and S3. Generally, water yield showed an increasing trend in most parts of the sub-basins between scenarios S1 and S0 and scenarios S2 and S0 and both an increase and a decrease in trends between S2 and S1 and between S3 and S2. However, the percentages of both increasing and decreasing trends were higher for this watershed than Meki watershed.

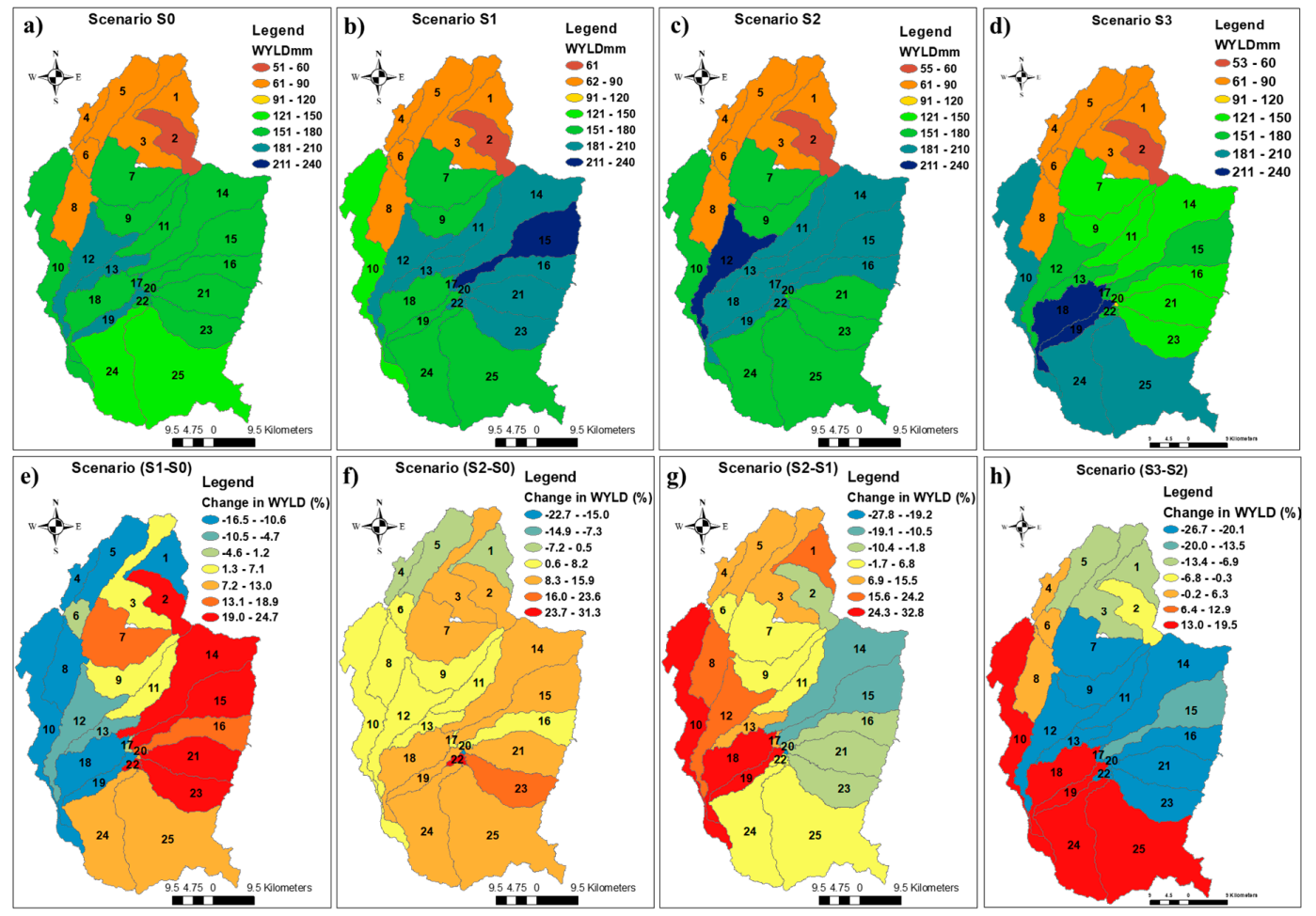

Figure 11. Spatial distribution of annual average and changing rates of WYLD for different land-use scenarios $(\mathbf{a}-\mathbf{c}, \mathbf{e}-\mathbf{g})$ and climate variability scenario $(\mathbf{d}, \mathbf{h})$ in Ketar watershed.

\subsection{Streamflow Responses to Different Scenarios}

\subsubsection{Monthly Streamflow Responses to Land-Use Scenarios}

The calibrated and validated SWAT model was used to simulate the monthly streamflow responses of different land use and climate scenarios. Monthly streamflow simulated using the same base period climate data for the different land-use scenarios (S0, S1, and S2) for Meki and Ketar watersheds are shown in Figures 12a and 13a, respectively. For both watersheds, the results show that the monthly scale streamflow responses were relatively similar for the different land-use scenarios with very few variations between peak monthly flows of scenario $\mathrm{S} 0$ and others.

The model reasonably simulated the time to peak and recession of peak streamflow in both watersheds. Relatively higher precipitations occurred in the months between June and August, resulting in higher streamflow and lower precipitations that occurred in the small rainy season from March to May and the corresponding low streamflow resulted. These higher and lower streamflow were also well simulated based on higher and lower precipitation amounts. For Meki watershed, very high streamflow occurred at the beginning of the 1990s while the streamflow in the 1980s was relatively less. However, in Ketar watershed, extremely higher streamflow occurred in the early 1980s and lower 
streamflows were observed in the late 1980s and beginning of the 1990s. The result showed that despite the land-use change scenarios considered, the change in extreme values of the monthly streamflows was more related to the change in the amount of precipitation than the changes in land use.
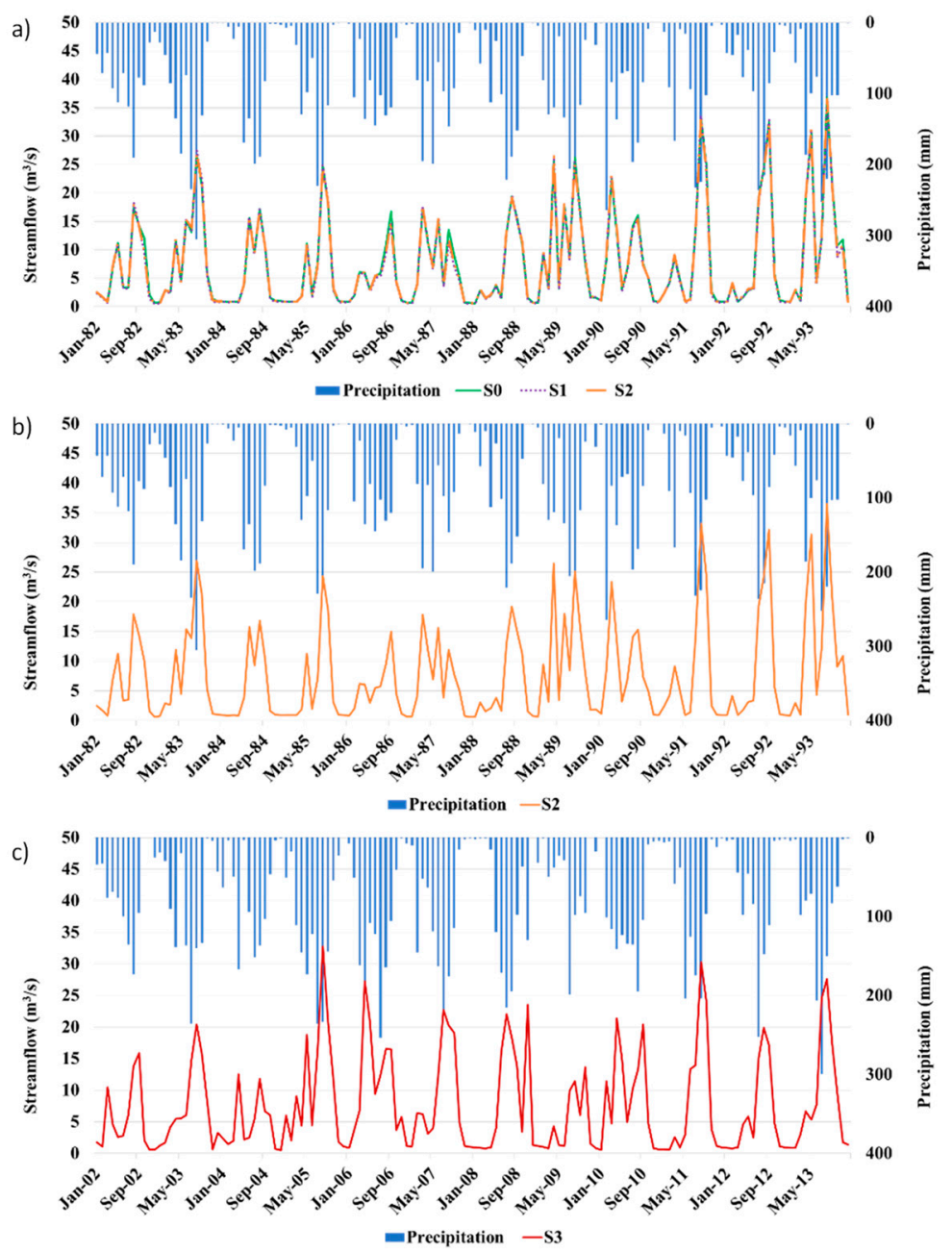

Figure 12. Monthly streamflow simulation for Meki watershed for different land-use scenarios (a) and different climate variability scenarios $(\mathbf{b}, \mathbf{c})$.

\subsubsection{Monthly Streamflow Responses to Climate Scenarios}

Scenarios S3 and S2 were developed to study the impacts of climate variability on the hydrologic response of the two watersheds in the Lake Ziway basin. The decrease in precipitation and variability in temperature changed the water balance of both watersheds more than the changes in land use (Tables 7 and 8). The impact of hydrologic responses of climate variability was observed to be more serious for Ketar watershed than Meki. Following a decrease in the amount of annual average precipitation, the average annual ET, surface runoff, and water yields also decreased for Ketar watershed and slightly for Meki. Figures $12 \mathrm{~b}$ and $13 \mathrm{~b}$ show the simulated monthly streamflow of Meki and Ketar watersheds, respectively, under scenario S2, and Figures $12 \mathrm{c}$ and $13 \mathrm{c}$ show the same simulation results under scenario S3. For both watersheds, compared to scenario S2, the relative peak streamflow in the rainy season showed a decline in the case of scenario S3. Specifically, for Ketar watershed, the extremely high streamflow shown in scenario S2 did not occur in scenario S3.

For Ketar watershed, an increase in streamflow by $6.8 \%$ and $8.3 \%$ for the land-use change scenarios $\mathrm{S} 1$ and S2 as compared to the base period scenario S0 and a decrease in streamflow by $5.8 \%$ for the climate variability scenario S3 as compared to S2 were observed. However, percentages of increase in streamflow due to changes in land use and a decrease in streamflow due to the change in climate 
variability were considerably less for Meki watershed. The reason is related to the relatively higher changes in ET between the land-use change scenarios and less change in the amount of precipitation.
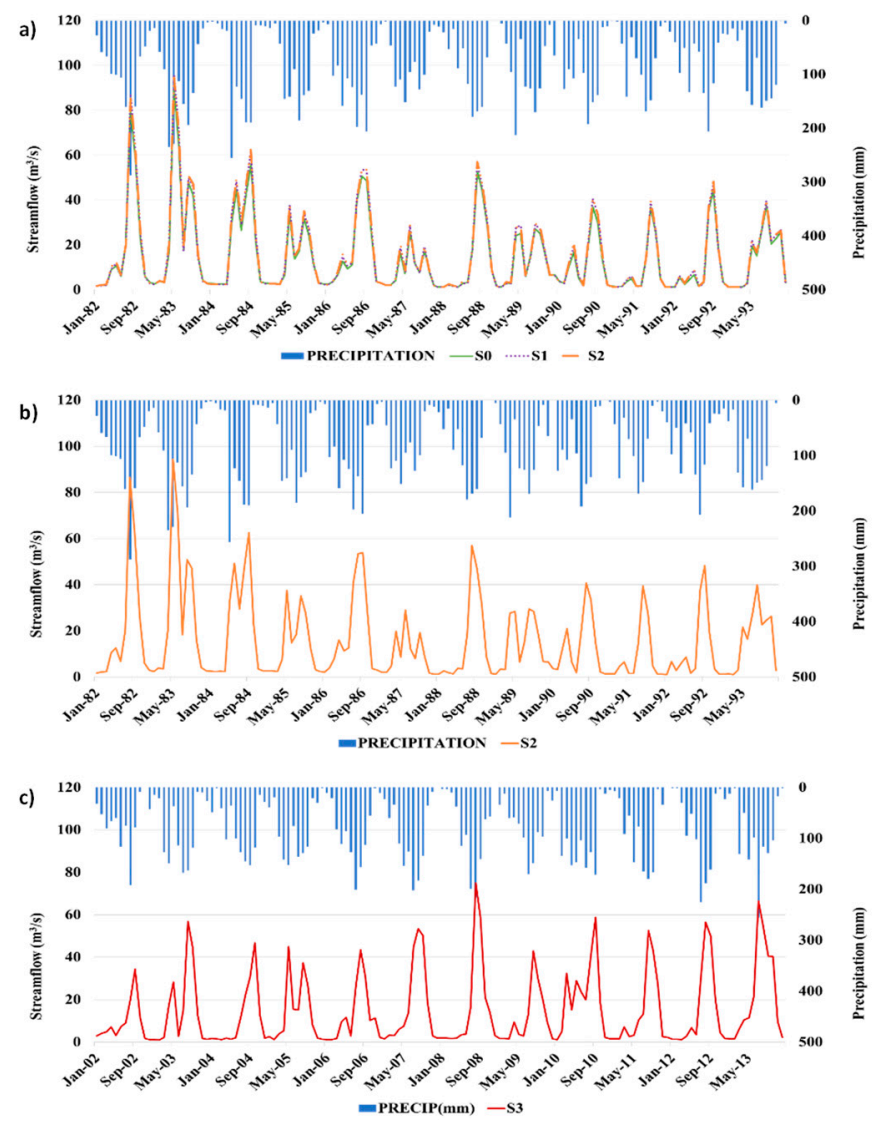

Figure 13. Monthly streamflow simulation for Ketar watershed for different land-use scenarios (a) and different climate variability scenarios $(\mathbf{b}, \mathbf{c})$.

\section{Discussion}

The hydrologic responses of a watershed can be affected by the changes in land use and climate variability. The impacts of these changes on the annual water balance, streamflow, and sediment yield and water quality have been studied using hydrologic models such as SWAT. The change in land use affects the water balance components of a basin by altering the $\mathrm{CN}$ values, while climate variabilities affect the water balance outputs following the changes in climate variables like precipitation and temperature. A decrease in vegetation cover when land-use classes such as woodlands are converted to agricultural or barren land would generally result in a decrease in evapotranspiration and rate of soil infiltration. Forestlands reduce the amount of water discharge from precipitation by increasing the rate of transpiration and the amount of interception. The more a watershed is covered by vegetation, especially forests, the less the amount of surface runoff and vice versa. Following the tillage and other human and farming equipment activities, the compaction of agricultural lands increases the bulk density of the soil, which ultimately reduces the rate of water infiltration [64]. It also increases the soil water retention capacity of the agricultural field. As the water demands of most of the crops are less compared to the forests, the soil moisture excess rainfall of agricultural lands generates more runoff than the woodlands [65]. The rate of increase in surface runoff is even more when a vegetation-covered land is converted to settlement, where the infrastructures and buildings reduce the rate of rainfall infiltration into the ground to nearly zero.

Studies showed that peak agricultural land expansion was observed in European countries during the 1940s and 1950s followed by the abandonment of the agricultural lands during the 1960s and 
1970 because of different socio-economic factors [66]. A similar long period LULC study in Ethiopian watershed also showed that the expansion in agricultural land was greater during the 1950s and 1960s than the periods during the end of the century $[67,68]$. Although the expansion rate decreased and finally stopped in the 1990s because of the lack of additional land for additional expansions as mentioned in the same study, abandonment of agricultural lands did not occur in most watersheds of Ethiopia. Rather, the land-use classes like agroforestry have been converted to an intensively cultivated agricultural area following the increase in population during the last few decades. Although the changes in land-use might not be higher, the impacts of the agricultural intensification and farming practices on the streamflow regimes cannot be ignored.

Land use classifications produced for the Lake Ziway basin have an acceptable accuracy based on the criteria developed by [61] showing that the changes in land use are reasonably identified. Cultivation and agroforestry are the major classes covering most parts of the area of the basin, while settlement and wetlands class area coverages are the least. Cultivation and settlement classes have shown a continuous increase between 1984, 2000, and 2017 (Table 4) and woodlands and afro-alpine classes have shown a considerable decrease, supporting the argument that following an increase in population, the expansion in agricultural and urban areas results in a decrease in woodlands and forest areas [69]. Getnet et al. [26] reported that between 1975 and 2008, the annual precipitation volume has not changed except the changes in temperature in some areas of the central rift valley basin. However, the results in Figures 4 and 5 indicate that the variability in average annual monthly precipitation and temperature has affected and changed the water balance of the two watersheds.

The changes in annual water balances of Meki and Ketar watersheds due to climate variability and land-use changes are shown in Tables 7 and 8, respectively. It can be observed from the results of the two tables that the impacts of changes in land use and climate on the water balance of the watersheds were more on Ketar than Meki. The possible reason was that the changes in land use among the different scenarios were more for Ketar watershed than Meki (Figure 2). Most of the afro-alpine and agroforestry land use classes, whose area changed between 1984 and 2017, were found in Ketar watershed. However, the change in land use of Meki watershed was relatively small since the area was already intensively cultivated starting from the earlier periods and the cultivation class of the basin was more concentrated in this watershed. Similarly, the decrease in average annual precipitation between scenarios S2 and S3 was higher for Ketar watershed than Meki, resulting in a considerable reduction in the water balance of Ketar watershed.

The results reported by similar studies indicated that the hydrologic variations in water balance due to climate variability was considerably more than those due to land-use change scenarios [44,45]. Comparing the simulated annual water balances of S0 with S2 and that of S2 with S3, it can be observed that both the land-use change and climate variability resulted in considerable hydrologic variations of the water balance in this study. The impacts of land-use change scenarios were more predominant in surface runoff and water yield than ET for Ketar watershed. Whereas, for Meki watershed, the impacts were more predominant in ET than surface runoff and water yield. However, the impacts of climate variability were more predominant in ET than surface runoff and water yield for both watersheds (Tables 7 and 8). Relatively linear hydrologic responses were observed for Ketar watershed for the different land use and climate variability scenarios, while the responses were non-linear for Meki. Non-linearity of hydrologic responses to the impacts of changes in different scenarios were also reported in previous studies $[2,45,70]$.

According to Wagner et al. [40] and Fohrer et al. [71], the impacts of the changes considered in different land-use scenarios on the annual water balance are relatively less and sometimes even too small to detect in the case of rivers with larger areas. Figures 8-11 show the spatial distribution patterns of the average annual ET and water yield and their changing rates of both watersheds for different land use and climate variability scenarios. The spatial distributions of the values help in understanding the impacts of changes in land use and climate on the hydrologic responses at smaller and sub-basins scales of each watershed. Following the relatively smaller changes in land use in Meki watershed, the 
average annual ET for the different land-use scenarios has changed in a few sub-basins, but the number of sub-basins whose average annual water yields have changed is more than that of the changes in ET (Figures 8 and 10). However, higher amounts of changes in both average annual ET and water yield of sub-basins for the different land-use scenarios were observed for Ketar watershed (Figures 9 and 11), showing that most of the land-use changes of Lake Ziway basin have happened in this watershed.

The change in climate variability has altered the average annual values of both ET and water yield in most of the sub-basins of both watersheds, indicating that the impact of land-use change on hydrologic responses is less than that of climate variability at sub-basin levels. The spatial distributions of the changing rates in ET and water yield of the sub-basin also indicated the extent of the impacts of the changes in land use and climate variability on the hydrologic responses at sub-basin levels. This information is quite helpful in identifying the sub-basins that are more affected by the changes and hence to implement different management practices to control the changes in hydrologic responses.

The calibrated model was also used to simulate the monthly streamflow of the two main feeder rivers of the Lake Ziway basin for the different scenarios developed (Figures 12 and 13). The results showed that the monthly streamflow simulated for the different land-use scenarios (S0, S1, and S2) have shown minor changes in both watersheds, however the monthly streamflow simulated for different climate scenarios have shown considerable changes. Similar results were reported by Zhang, et al. [44] showing that the impact of the change in land uses on the monthly streamflow is less than that of the changes in climate variables.

\section{Conclusions}

The impacts of changes in land-use and climate variability on the hydrologic responses of Meki and Ketar watersheds of Lake Ziway basin were assessed in this study using the SWAT hydrologic model for the different scenarios developed (S0, S1, S2, and S3). Between 1984 and 2017, the increase in cultivation and settlement areas and a decrease in afro-alpine and woodland classes were the dominant changes in land-use observed. Similarly, the differences in average annual monthly precipitation and temperature between the periods from 1980 to 1993 and from 2000 to 2013 showed the climate variability in the region.

The average annual water balance, the spatial distribution patterns and changing rates of annual ET and water yield, and the monthly streamflow simulations were evaluated using the calibrated and validated SWAT model. From the hydrologic modeling results, it was observed that the changes in land uses resulted in an increase in average annual surface runoff and water yield by $14.3 \mathrm{~mm}$ and $11.9 \mathrm{~mm}$, respectively, for Ketar watershed. Similarly, the change in land-use between 1984 and 2000 resulted in an increase in average annual ET by $7.9 \mathrm{~mm}$ and a minor change in surface runoff and water yield for Meki watershed. Using the same land-use for the climate variability scenarios analysis, the change in precipitation and temperature resulted in a decrease in average annual ET, surface runoff, and water yield by $19.3 \mathrm{~mm}, 7.1 \mathrm{~mm}$, and $9.0 \mathrm{~mm}$, respectively, for Ketar watershed and decrease in ET by $20.6 \mathrm{~mm}$ and minor changes in surface runoff and water yield for Meki watershed. In both watersheds, the spatial distribution patterns of ET and water yield of the sub-basins and the monthly streamflow showed considerable changes when scenario S3 was compared with scenario S2. The overall analysis of this study showed that the impacts of climate variability on the streamflow of Lake Ziway basin are more than the impacts of the changes in land use. Furthermore, both the changes in land-use and climate variability affected the annual water balance of Ketar watershed more than Meki. It is also highly recommended to study the impacts of future climate and land-use changes on the water resources of the central rift valley basin of Ethiopia.

Author Contributions: M.M. conceived of, designed, performed the analysis, and wrote the paper as part of his Ph.D. dissertation. S.S. supervised the research scholar. I.C. also provided help throughout the work. All coauthors have collaborated on the redaction of the manuscript. All authors have read and agreed to the published version of the manuscript.

Funding: This research received no external funding. 
Acknowledgments: The authors would like to acknowledge the Ministry of Water Resources of Ethiopia and Ethiopian National Meteorological Agency for providing the hydrological and climatological data. The first author would like to express his appreciation to Indian Council for Cultural Relations for the financial support during his Ph.D. work, and the facilities provided by the Department of Hydrology, Indian Institute of Technology Roorkee.

Conflicts of Interest: The authors declare no conflict of interest.

\section{Appendix A}

Table A1. Mann-Kendall test statistic and Sen's slope estimates for monthly and annual mean temperatures of five weather stations in Lake Ziway basin during 1980-2013.

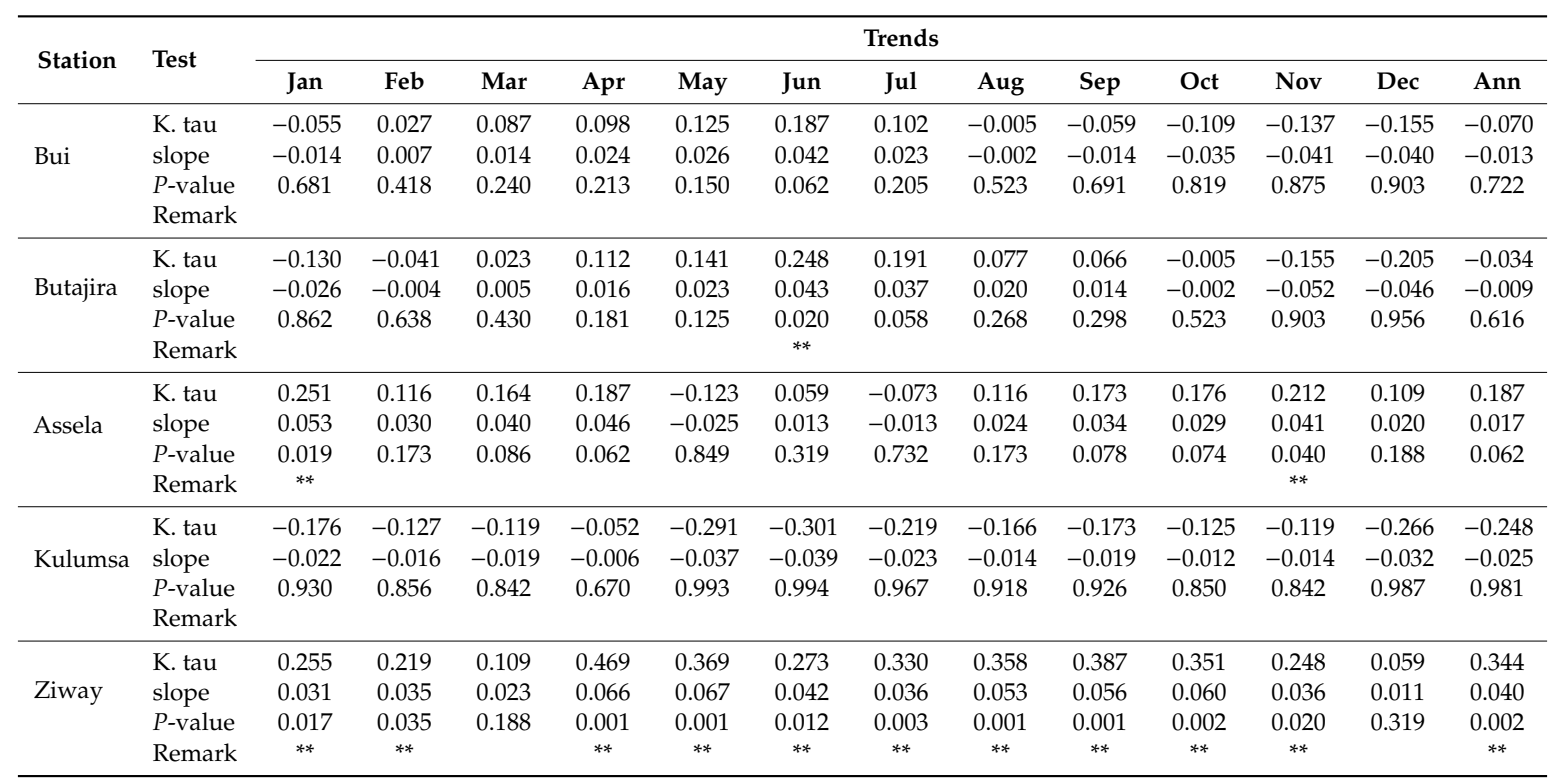

(**) Means significant at $P<0.05$

Table A2. Mann-Kendall test statistic and Sen's slope estimates for monthly and annual precipitation of nine weather stations in Lake Ziway basin during 1980-2013.

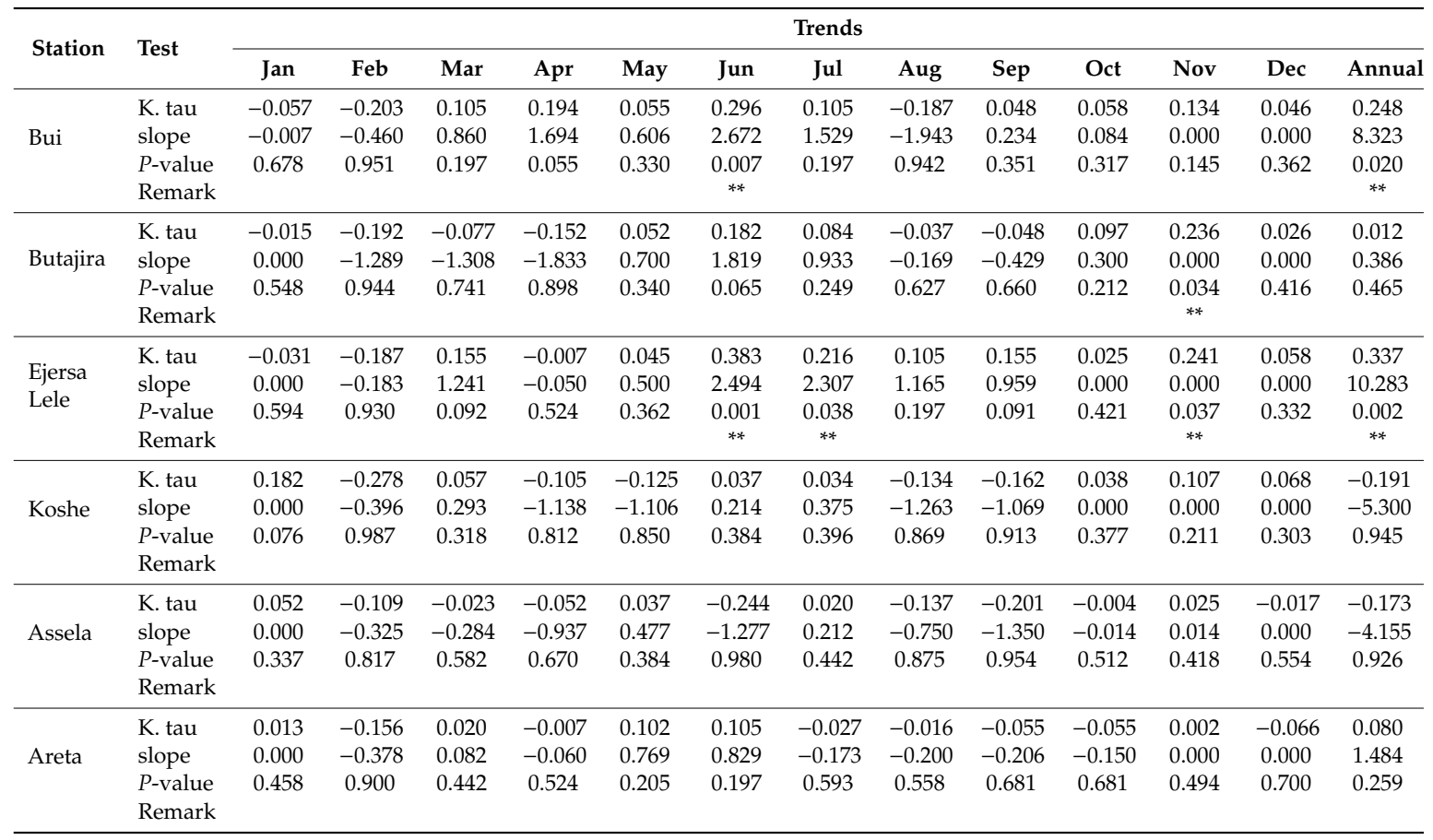


Table A2. Cont.

\begin{tabular}{|c|c|c|c|c|c|c|c|c|c|c|c|c|c|c|}
\hline \multirow{2}{*}{ Station } & \multirow{2}{*}{ Test } & \multicolumn{13}{|c|}{ Trends } \\
\hline & & Jan & Feb & Mar & Apr & May & Jun & Jul & Aug & Sep & Oct & Nov & Dec & Annual \\
\hline \multirow{4}{*}{ Degaga } & K. tau & -0.016 & -0.256 & -0.070 & -0.262 & 0.123 & 0.187 & 0.241 & 0.102 & 0.159 & 0.002 & -0.066 & -0.108 & 0.020 \\
\hline & slope & 0.000 & -0.836 & -0.300 & -1.818 & 1.264 & 1.310 & 1.899 & 0.631 & 0.763 & 0.000 & -0.077 & -0.100 & 0.243 \\
\hline & $P$-value & 0.553 & 0.983 & 0.722 & 0.986 & 0.158 & 0.062 & 0.023 & 0.205 & 0.097 & 0.500 & 0.709 & 0.814 & 0.442 \\
\hline & Remark & & & & & & & $* *$ & & & & & & \\
\hline \multirow{4}{*}{ Kulumsa } & K. tau & 0.093 & -0.144 & -0.004 & -0.087 & 0.068 & 0.029 & 0.105 & 0.002 & 0.027 & -0.030 & 0.140 & -0.101 & 0.016 \\
\hline & slope & 0.045 & -0.550 & -0.025 & -0.865 & 0.455 & 0.082 & 0.618 & 0.027 & 0.146 & -0.118 & 0.039 & 0.000 & 0.100 \\
\hline & $P$-value & 0.224 & 0.882 & 0.512 & 0.769 & 0.287 & 0.406 & 0.197 & 0.500 & 0.418 & 0.604 & 0.130 & 0.793 & 0.453 \\
\hline & Remark & & & & & & & & & & & & & \\
\hline \multirow{4}{*}{ Ziway } & K. tau & 0.097 & -0.139 & 0.020 & 0.066 & 0.098 & 0.258 & 0.351 & -0.027 & 0.187 & -0.022 & 0.355 & 0.156 & 0.155 \\
\hline & slope & 0.037 & -0.267 & 0.156 & 0.441 & 0.691 & 1.369 & 2.577 & -0.233 & 0.831 & 0.000 & 0.000 & 0.000 & 3.406 \\
\hline & $P$-value & 0.217 & 0.872 & 0.442 & 0.298 & 0.213 & 0.016 & 0.002 & 0.593 & 0.062 & 0.571 & 0.003 & 0.113 & 0.096 \\
\hline & Remark & & & & & & $* *$ & $* *$ & & & & $\not x$ & & \\
\hline
\end{tabular}

$\left.{ }^{* *}\right)$ Means significant at $P<0.05$.

\section{References}

1. Changnon, S.A.; Demissie, M. Detection of changes in streamflow and floods resulting from climate fluctuations and land use-drainage changes. Clim. Chang. 1996, 32, 411-421. [CrossRef]

2. Khoi, D.N.; Suetsugi, T. The responses of hydrological processes and sediment yield to land-use and climate change in the Be River Catchment, Vietnam. Hydrol. Process. 2014, 28, 640-652. [CrossRef]

3. Wang, S.; Kang, S.; Zhang, L.; Li, F. Modelling hydrological response to different land-use and climate change scenarios in the Zamu River basin of northwest China. Hydrol. Process. Int. J. 2008, 22, 2502-2510. [CrossRef]

4. Buytaert, W.; Célleri, R.; De Bièvre, B.; Cisneros, F.; Wyseure, G.; Deckers, J.; Hofstede, R. Human impact on the hydrology of the Andean páramos. Earth Sci. Rev. 2006, 79, 53-72. [CrossRef]

5. Li, Z.; Liu, W.-Z.; Zhang, X.-C.; Zheng, F.-L. Impacts of land use change and climate variability on hydrology in an agricultural catchment on the Loess Plateau of China. J. Hydrol. 2009, 377, 35-42. [CrossRef]

6. Niraula, R.; Meixner, T.; Norman, L.M. Determining the importance of model calibration for forecasting absolute/relative changes in streamflow from LULC and climate changes. J. Hydrol. 2015, 522, 439-451. [CrossRef]

7. Wang, R.; Kalin, L.; Kuang, W.; Tian, H. Individual and combined effects of land use/cover and climate change on Wolf Bay watershed streamflow in southern Alabama. Hydrol. Process. 2014, 28, 5530-5546. [CrossRef]

8. Legesse, D.; Vallet-Coulomb, C.; Gasse, F. Hydrological response of a catchment to climate and land use changes in Tropical Africa: Case study South Central Ethiopia. J. Hydrol. 2003, 275, 67-85. [CrossRef]

9. Li, K.; Coe, M.; Ramankutty, N.; De Jong, R. Modeling the hydrological impact of land-use change in West Africa. J. Hydrol. 2007, 337, 258-268. [CrossRef]

10. Adrian, R.; O’Reilly, C.M.; Zagarese, H.; Baines, S.B.; Hessen, D.O.; Keller, W.; Livingstone, D.M.; Sommaruga, R.; Straile, D.; Van Donk, E. Lakes as sentinels of climate change. Limnol. Oceanogr. 2009, 54, 2283-2297. [CrossRef]

11. Coe, M.T.; Foley, J.A. Human and natural impacts on the water resources of the Lake Chad basin. J. Geophys. Res. Atmos. 2001, 106, 3349-3356. [CrossRef]

12. Williamson, C.E.; Saros, J.E.; Vincent, W.F.; Smol, J.P. Lakes and reservoirs as sentinels, integrators, and regulators of climate change. Limnol. Oceanogr. 2009, 54, 2273-2282. [CrossRef]

13. Birkett, C. Synergistic remote sensing of Lake Chad: Variability of basin inundation. Remote Sens. Environ. 2000, 72, 218-236. [CrossRef]

14. Lemoalle, J.; Bader, J.-C.; Leblanc, M.; Sedick, A. Recent changes in Lake Chad: Observations, simulations and management options (1973-2011). Glob. Planet. Chang. 2012, 80, 247-254. [CrossRef]

15. Wald, L. Monitoring the decrease of Lake Chad from space. Geocarto Int. 1990, 5, 31-36. [CrossRef]

16. Hutchinson, C.F.; Warshall, P.; Arnould, E.J.; Kindler, J. Development in Arid Lands Lessons from Lake Chad. Environ. Sci. Policy Sustain. Dev. 1992, 34, 16-43. [CrossRef]

17. Ayenew, T. Environmental implications of changes in the levels of lakes in the Ethiopian Rift since 1970. Reg. Environ. Chang. 2004, 4, 192-204. [CrossRef] 
18. Tessema, Z. Hydrochemical and Water Balance Approach in the Study of High Water Level Rise of Lake Beseka. Master's Thesis, University of Birmingham, Birmingham, UK, 1998.

19. Geremew, Z. Engineering Geological Investigation and Lake Level Changes in the Awassa Basin. Master's Thesis, Addis Ababa University, Department of Geology ad Geophysics, Addis Ababa, Ethiopia, 2000.

20. Tegaye, T.A. The Hydrogeological System of the Lake District Basin: Central Main Ethiopian Rift; International Institute for Aerospace Survey and Earth Sciences: Enschede, The Netherlands, 1998.

21. Lemma, B. Seasonal limnological studies on Lake Alemaya: A tropical African lake, Ethiopia. Arch. Hydrobiol. Suppl. Algol. Stud. 1995, 107, 263-285.

22. Lemma, B. Ecological changes in two Ethiopian lakes caused by contrasting human intervention. Limnol. Ecol. Manag. Inland Waters 2003, 33, 44-53. [CrossRef]

23. Muleta, S.; Yohannes, F.; Rashid, S. Soil erosion assessment of Lake Alemaya catchment, Ethiopia. Land Degrad. Dev. 2006, 17, 333-341. [CrossRef]

24. Ayenew, T.; Legesse, D. The changing face of the Ethiopian rift lakes and their environs: Call of the time. Lakes Reserv. Res. Manag. 2007, 12, 149-165. [CrossRef]

25. Hengsdijk, H.; Jansen, H. Agricultural development in the Central Ethiopian Rift valley: A desk-study on water-related issues and knowledge to support a policy dialogue. Plant Res. Int. 2006, 22, 28-36.

26. Getnet, M.; Hengsdijk, H.; van Ittersum, M. Disentangling the impacts of climate change, land use change and irrigation on the Central Rift Valley water system of Ethiopia. Agric. Water Manag. 2014, 137, 104-115. [CrossRef]

27. Desta, H.; Lemma, B.; Gebremariam, E. Identifying sustainability challenges on land and water uses: The case of Lake Ziway watershed, Ethiopia. Appl. Geogr. 2017, 88, 130-143. [CrossRef]

28. Chiang, L.; Chaubey, I.; Gitau, M.W.; Arnold, J.G. Differentiating impacts of land use changes from pasture management in a CEAP watershed using the SWAT model. Trans. ASABE 2010, 53, 1569-1584. [CrossRef]

29. Chiang, L.-C.; Chaubey, I.; Hong, N.-M.; Lin, Y.-P.; Huang, T. Implementation of BMP strategies for adaptation to climate change and land use change in a pasture-dominated watershed. Int. J. Environ. Res. Public Health 2012, 9, 3654-3684. [CrossRef] [PubMed]

30. Farjad, B.; Gupta, A.; Razavi, S.; Faramarzi, M.; Marceau, D. An integrated modelling system to predict hydrological processes under climate and land-use/cover change scenarios. Water 2017, 9, 767. [CrossRef]

31. Guo, J.; Su, X.; Singh, V.; Jin, J. Impacts of climate and land use/cover change on streamflow using SWAT and a separation method for the Xiying River Basin in northwestern China. Water 2016, 8, 192. [CrossRef]

32. Pan, S.; Liu, D.; Wang, Z.; Zhao, Q.; Zou, H.; Hou, Y.; Liu, P.; Xiong, L. Runoff responses to climate and land use/cover changes under future scenarios. Water 2017, 9, 475. [CrossRef]

33. Rafiei Emam, A.; Mishra, B.; Kumar, P.; Masago, Y.; Fukushi, K. Impact assessment of climate and land-use changes on flooding behavior in the Upper Ciliwung River, Jakarta, Indonesia. Water 2016, 8, 559. [CrossRef]

34. Stefanidis, K.; Kostara, A.; Papastergiadou, E. Implications of human activities, land use changes and climate variability in Mediterranean lakes of Greece. Water 2016, 8, 483. [CrossRef]

35. Gebremicael, T.; Mohamed, Y.; Betrie, G.; van der Zaag, P.; Teferi, E. Trend analysis of runoff and sediment fluxes in the Upper Blue Nile basin: A combined analysis of statistical tests, physically-based models and landuse maps. J. Hydrol. 2013, 482, 57-68. [CrossRef]

36. Akale, A.T.; Dagnew, D.C.; Moges, M.A.; Tilahun, S.A.; Steenhuis, T.S. The Effect of Landscape Interventions on Groundwater Flow and Surface Runoff in a Watershed in the Upper Reaches of the Blue Nile. Water 2019, 11, 2188. [CrossRef]

37. Anand, J.; Gosain, A.K.; Khosa, R. Prediction of land use changes based on Land Change Modeler and attribution of changes in the water balance of Ganga basin to land use change using the SWAT model. Sci. Total Environ. 2018, 644, 503-519. [CrossRef] [PubMed]

38. Gashaw, T.; Tulu, T.; Argaw, M.; Worqlul, A.W. Modeling the hydrological impacts of land use/land cover changes in the Andassa watershed, Blue Nile Basin, Ethiopia. Sci. Total Environ. 2018, 619, 1394-1408. [CrossRef] [PubMed]

39. Kundu, S.; Khare, D.; Mondal, A. Past, present and future land use changes and their impact on water balance. J. Environ. Manag. 2017, 197, 582-596. [CrossRef]

40. Wagner, P.; Kumar, S.; Schneider, K. An assessment of land use change impacts on the water resources of the Mula and Mutha Rivers catchment upstream of Pune, India. Hydrol. Earth Syst. Sci. 2013, 17, 2233-2246. [CrossRef] 
41. Woldesenbet, T.A.; Elagib, N.A.; Ribbe, L.; Heinrich, J. Hydrological responses to land use/cover changes in the source region of the Upper Blue Nile Basin, Ethiopia. Sci. Total Environ. 2017, 575, 724-741. [CrossRef]

42. Zhang, L.; Nan, Z.; Yu, W.; Zhao, Y.; Xu, Y. Comparison of baseline period choices for separating climate and land use/land cover change impacts on watershed hydrology using distributed hydrological models. Sci. Total Environ. 2018, 622, 1016-1028. [CrossRef]

43. Zuo, D.; Xu, Z.; Yao, W.; Jin, S.; Xiao, P.; Ran, D. Assessing the effects of changes in land use and climate on runoff and sediment yields from a watershed in the Loess Plateau of China. Sci. Total Environ. 2016, 544, 238-250. [CrossRef]

44. Zhang, L.; Karthikeyan, R.; Bai, Z.; Srinivasan, R. Analysis of streamflow responses to climate variability and land use change in the Loess Plateau region of China. Catena 2017, 154,1-11. [CrossRef]

45. Zhang, L.; Nan, Z.; Xu, Y.; Li, S. Hydrological impacts of land use change and climate variability in the headwater region of the Heihe River Basin, Northwest China. PLoS ONE 2016, 11, e0158394. [CrossRef] [PubMed]

46. Musie, M.; Sen, S.; Srivastava, P. Comparison and Evaluation of Gridded Precipitation Datasets for Streamflow Simulation in Data Scarce Watersheds of Ethiopia. J. Hydrol. 2019, 579, 124168. [CrossRef]

47. Pascual-Ferrer, J.; Pérez-Foguet, A.; Codony, J.; Raventós, E.; Candela, L. Assessment of water resources management in the Ethiopian Central Rift Valley: Environmental conservation and poverty reduction. Int. J. Water Resour. Dev. 2014, 30, 572-587. [CrossRef]

48. Ayenew, T. Evapotranspiration estimation using thematic mapper spectral satellite data in the Ethiopian rift and adjacent highlands. J. Hydrol. 2003, 279, 83-93. [CrossRef]

49. Vallet-Coulomb, C.; Legesse, D.; Gasse, F.; Travi, Y.; Chernet, T. Lake evaporation estimates in tropical Africa (Lake Ziway, Ethiopia). J. Hydrol. 2001, 245, 1-18. [CrossRef]

50. Wagner, P.D.; Bhallamudi, S.M.; Narasimhan, B.; Kumar, S.; Fohrer, N.; Fiener, P. Comparing the effects of dynamic versus static representations of land use change in hydrologic impact assessments. Environ. Model. Softw. 2017, 122, 103987. [CrossRef]

51. Wagner, P.D.; Bhallamudi, S.M.; Narasimhan, B.; Kantakumar, L.N.; Sudheer, K.; Kumar, S.; Schneider, K.; Fiener, P. Dynamic integration of land use changes in a hydrologic assessment of a rapidly developing Indian catchment. Sci. Total Environ. 2016, 539, 153-164. [CrossRef]

52. Chu, H.J.; Lin, Y.P.; Huang, C.W.; Hsu, C.Y.; Chen, H.Y. Modelling the hydrologic effects of dynamic land-use change using a distributed hydrologic model and a spatial land-use allocation model. Hydrol. Process. 2010, 24, 2538-2554. [CrossRef]

53. Congalton, R.G.; Green, K. Assessing the Accuracy of Remotely Sensed Data: Principles and Practices; CRC Press: Boca Raton, FL, USA, 2008.

54. Kendall, M.G. Rank Correlation Methods; Griffin: London, UK, 1948.

55. Mann, H.B. Nonparametric tests against trend. Econom. J. Econom. Soc. 1945, 13, 245-259. [CrossRef]

56. Shao, G.; Guan, Y.; Zhang, D.; Yu, B.; Zhu, J. The impacts of climate variability and land use change on streamflow in the Hailiutu river basin. Water 2018, 10, 814. [CrossRef]

57. Sen, P.K. Estimates of the regression coefficient based on Kendall's tau. J. Am. Stat. Assoc. 1968, 63, 1379-1389. [CrossRef]

58. Arnold, J.G.; Srinivasan, R.; Muttiah, R.S.; Williams, J.R. Large area hydrologic modeling and assessment part I: Model development. JAWRA J. Am. Water Resour. Assoc. 1998, 34, 73-89. [CrossRef]

59. Neitsch, S.L.; Arnold, J.G.; Kiniry, J.R.; Williams, J.R. Soil and Water Assessment Tool Theoretical Documentation Version 2009; Texas Water Resources Institute: College Station, TX, USA, 2011.

60. Abbaspour, K.; Vejdani, M.; Haghighat, S.; Yang, J. SWAT-CUP calibration and uncertainty programs for SWAT. In MODSIM 2007 International Congress on Modelling and Simulation; Modelling and Simulation Society of Australia and New Zealand: Canberra, Australia, 2007; pp. 1596-1602.

61. Landis, J.R.; Koch, G.G. The measurement of observer agreement for categorical data. Biometrics 1977, 159-174. [CrossRef]

62. Chen, Y.; Takeuchi, K.; Xu, C.; Chen, Y.; Xu, Z. Regional climate change and its effects on river runoff in the Tarim Basin, China. Hydrol. Process. Int. J. 2006, 20, 2207-2216. [CrossRef]

63. Wang, G.; Xia, J.; Chen, J. Quantification of effects of climate variations and human activities on runoff by a monthly water balance model: A case study of the Chaobai River basin in northern China. Water Resour. Res. 2009, 45. [CrossRef] 
64. Abu-Hamdeh, N.H. Compaction and subsoiling effects on corn growth and soil bulk density. Soil Sci. Soc. Am. J. 2003, 67, 1213-1219. [CrossRef]

65. Githui, F.; Mutua, F.; Bauwens, W. Estimating the impacts of land-cover change on runoff using the soil and water assessment tool (SWAT): Case study of Nzoia catchment, Kenya/Estimation des impacts du changement d'occupation du sol sur l'écoulement à l'aide de SWAT: Étude du cas du bassin de Nzoia, Kenya. Hydrol. Sci. J. 2009, 54, 899-908.

66. Xystrakis, F.; Psarras, T.; Koutsias, N. A process-based land use/land cover change assessment on a mountainous area of Greece during 1945-2009: Signs of socio-economic drivers. Sci. Total Environ. 2017, 587, 360-370. [CrossRef]

67. Teferi, E.; Bewket, W.; Uhlenbrook, S.; Wenninger, J. Understanding recent land use and land cover dynamics in the source region of the Upper Blue Nile, Ethiopia: Spatially explicit statistical modeling of systematic transitions. Agric. Ecosyst. Environ. 2013, 165, 98-117. [CrossRef]

68. Tekleab, S.; Mohamed, Y.; Uhlenbrook, S.; Wenninger, J. Hydrologic responses to land cover change: The case of Jedeb mesoscale catchment, Abay/Upper Blue Nile basin, Ethiopia. Hydrol. Process. 2014, 28, 5149-5161. [CrossRef]

69. Li, Y.; Zhao, S.; Zhao, K.; Xie, P.; Fang, J. Land-cover changes in an urban lake watershed in a mega-city, central China. Environ. Monit. Assess. 2006, 115, 349-359. [CrossRef] [PubMed]

70. Park, J.-Y.; Park, M.-J.; Joh, H.-K.; Shin, H.-J.; Kwon, H.-J.; Srinivasan, R.; Kim, S.-J. Assessment of MIROC3. 2 HiRes climate and CLUE-s land use change impacts on watershed hydrology using SWAT. Trans. ASABE 2011, 54, 1713-1724. [CrossRef]

71. Fohrer, N.; Haverkamp, S.; Eckhardt, K.; Frede, H.-G. Hydrologic response to land use changes on the catchment scale. Phys. Chem. Earth Part B Hydrol. Ocean. Atmos. 2001, 26, 577-582. [CrossRef]

(C) 2020 by the authors. Licensee MDPI, Basel, Switzerland. This article is an open access article distributed under the terms and conditions of the Creative Commons Attribution (CC BY) license (http://creativecommons.org/licenses/by/4.0/). 